\title{
11. INTERSTITIAL WATER STUDIES, LEG 15 - A COMPARISON OF THE MAJOR ELEMENT AND CARBONATE CHEMISTRY DATA FROM SITES 147, 148, and $149^{1}$
}

\author{
Douglas E. Hammond, Lamont-Doherty Geological Observatory, Columbia University Palisades, New York
}

\begin{abstract}
Examination of analytical results reported by various investigators for the major elements in the pore waters collected on Leg 15 reveals that $\left[\mathrm{Cl}^{-}\right],\left[\mathrm{SO}_{4}{ }^{*}\right],\left[\mathrm{Na}^{+}\right],\left[\mathrm{K}^{+}\right]$, and $\left[\mathrm{Mg}^{++}\right]$ determinations agree well and may be reliable to $1 \%, 6 \%, 1.5 \%$, $5 \%$, and $2.5 \%$, respectively. $\left[\mathrm{Ca}^{++}\right]$, determined by titration (SIO), appears reliable to $\pm 5 \%$, but atomic absorption analyses tend to be systematically high, a problem which becomes more pronounced with depth. A model for apparent constant estimation (MACE) has been developed to facilitate comparison of the carbonate parameters which were measured ( $\Sigma$ alkalinity, $\Sigma \mathrm{CO}_{2}$, $p \mathrm{H}$, and $\left.p_{\mathrm{CO}_{2}}\right)$. Alkalinity calculated from $\Sigma \mathrm{CO}_{2}$ and $p \mathrm{CO}_{2}$ laboratory measurements agrees with shipboard titrations, but calculation of $\Sigma \mathrm{CO}_{2}$ from alkalinity and $p \mathrm{H}$ measurements suggests that some $\mathrm{CO}_{2}$ loss has occurred between pore water extrusion and $\Sigma \mathrm{CO}_{2}$ analysis. Punch-in $p \mathrm{H}$ measurements are consistent with gas pocket $p_{\mathrm{CO}_{2}}$ within $0.2 \mathrm{pH}$ units at Site 147, but are systematically lower than $\mathrm{pH}$ measurements on extruded water at Sites 147 and 148. This may be due to liquid junction potentials but is more likely attributable to $\mathrm{CO}_{2}$ loss during extrusion.

MACE is used to calculate $\Omega$, the degree of saturation of calcite in pore waters, and to elucidate the nature and magnitude of chemical changes in interstitial water as temperature and pressure are changed from in situ conditions. Clay minerals are shown to act as a source of strong acids as sediment temperature is increased. Pore water can exchange material with calcite and may attain equilibrium in the absence of organic matter. Because of this, squeezing temperature and pressure should be monitored.
\end{abstract}

\section{INTRODUCTION}

The aim of the DSDP pore water probram is to use interstitial water composition to define diagenetic mechanisms and rates. This requires a knowledge of in situ conditions, and several complications must be considered. Contamination of interstitial water with seawater may occur during drilling. Gas may be lost from cores with high gas pressure. Temperature and pressure during pore water extrusion differ from in situ conditions.

The intensive geochemical sampling done on Leg 15 offered an opportunity to examine the effects of these complications and a chance to compare several different types of measurements and estimate the confidence which may be placed in each. Of particular interest is the carbonate system, the one which is quite likely to be affected by temperature and pressure perturbations from in situ conditions.

\section{MAJOR ELEMENT COMPOSITION}

Three investigators analyzed complete profiles of pore water: Sayles et al. (WHOI) determined major and minor

\footnotetext{
${ }^{1}$ Lamont-Doherty Contribution No. 1834 .
}

constituents of samples squeezed at $4^{\circ} \mathrm{C}$ (abbreviated CS) and $22^{\circ} \mathrm{C}$ (abbreviated WS), Presley et al. (TAMU) determined major and minor constituents of CS samples; and Gieskes (SIO) determined calcium, magnesium, and total alkalinity of CS and WS samples. Table 1 contains a combination of their data selected to best represent the pore water composition of each sample. Procedures used in this selection, systematic differences, and suggested confidence limits (followed in parentheses by the fraction of samples falling within these limits) are discussed in the following paragraphs. All data for $\left[\mathrm{Mg}^{++}\right]$and $\left[\mathrm{Ca}^{++}\right]$, which are particularly important in discussing the carbonate chemistry, are plotted in Figures 1 to 12 and are tabulated by each investigator elsewhere in this volume.

\section{$\mathrm{Cl}^{-}$}

TAMU determines chloride using a titration with $\mathrm{Hg}\left(\mathrm{NO}_{3}\right)_{2}$ and a visual end point. WHOI does a Mohr titration using $\mathrm{AgNO}_{3}$ and a potentiometric end point. The two sets of data generally agree within $\pm 1 \%$ (32/47), although TAMU values are systematically about $1 \frac{1}{2} \%$ greater at Sites 147 and 148. Since the WHOI data show a smoother profile with depth, they are selected as superior. 
TABLE 1

Pore Water Composition ${ }^{a}$

\begin{tabular}{|c|c|c|c|c|c|c|c|c|}
\hline Sample & Depth & Type & $\mathrm{Cl}$ & $\mathrm{K}$ & $\mathrm{CA}$ & $\mathrm{Mg}$ & $\mathrm{SO}_{4}$ & Alk. \\
\hline $147 \mathrm{~B}-1-2$ & 2.5 & CS & 20.00 & 8.58 & 6.25 & 51.48 & 10.20 & 14.57 \\
\hline $147 \mathrm{~B}-1-3$ & 4.2 & CS & 20.14 & 8.69 & 3.71 & 47.12 & 5.62 & 17.72 \\
\hline $147 \mathrm{~B}-1-4$ & 4.7 & CS & 19.93 & 7.85 & 2.42 & 49.01 & 3.33 & 17.60 \\
\hline $147 \mathrm{~B}-1-4$ & 4.8 & CS & 19.85 & 7.41 & 2.09 & 45.58 & 0.52 & 17.13 \\
\hline $147 \mathrm{~B}-1-4$ & 5.1 & $\mathrm{CS}$ & 19.88 & 7.16 & 1.99 & 43.60 & 0.31 & 15.17 \\
\hline $147 \mathrm{~B}-2-3 / 4$ & 8.5 & CS & 19.91 & 7.58 & 3.21 & 47.82 & 4.68 & 17.71 \\
\hline $147 \mathrm{~B}-2-2$ & 15.0 & CS & 19.97 & 8.95 & 9.14 & 55.17 & 23.63 & 8.18 \\
\hline $147 \mathrm{~B}-2-6$ & 21.0 & CS & 20.02 & 6.90 & 4.17 & 43.47 & 0.31 & 13.75 \\
\hline $146 \mathrm{~B}-4-3 / 4$ & 28.0 & CS & 19.91 & 7.53 & 5.23 & 41.59 & 0.72 & 13.50 \\
\hline $147 \mathrm{~B}-6-2$ & 51.0 & $\mathrm{CS}$ & 19.48 & 8.18 & 3.58 & 30.02 & 1.35 & 10.06 \\
\hline $147 \mathrm{~B}-8-2 / 3$ & 63.0 & CS & 19.19 & 7.92 & 5.23 & 30.90 & 0.93 & 21.25 \\
\hline $147 \mathrm{~B}-7-4$ & 63.0 & CS & 19.07 & 8.75 & 5.23 & 30.21 & 0.41 & 24.64 \\
\hline 147B-9-4 & 83.0 & CS & 18.64 & 8.32 & 6.00 & 27.40 & 0.10 & 27.76 \\
\hline $147-10-3 / 4$ & 82.0 & CS & 18.97 & 7.92 & 7.03 & 29.61 & 1.35 & 28.00 \\
\hline $147 \mathrm{~B}-11-3$ & 100.0 & $\mathrm{CS}$ & 18.48 & 8.69 & 5.32 & 29.34 & 1.66 & 30.00 \\
\hline $147 \mathrm{C} \cdot 2-1$ & 126.0 & CS & 18.26 & 8.46 & 6.00 & 29.48 & 2.29 & 32.89 \\
\hline $147 C-4-4$ & 148.0 & CS & 18.15 & 8.74 & 6.25 & 26.33 & 2.08 & 31.36 \\
\hline $147 \mathrm{C}-7-4$ & 176.0 & CS & 17.83 & 6.90 & 6.15 & 25.18 & 0.00 & 23.74 \\
\hline $148-1-2$ & 3.0 & CS & 19.58 & 9.97 & 9.73 & 53.78 & 27.06 & 2.83 \\
\hline $148-1-4$ & 6.0 & $\mathrm{CS}$ & 19.49 & 10.01 & 9.12 & 53.66 & 25.92 & 4.00 \\
\hline $148-2-1$ & 11.0 & CS & 19.47 & 9.46 & 7.90 & 52.79 & 24.35 & 3.51 \\
\hline $148-2-3$ & 13.0 & CS & 19.56 & 9.47 & 7.47 & 52.05 & 23.11 & 4.43 \\
\hline $148-3-3$ & 22.0 & $\mathrm{CS}$ & 19.48 & 9.46 & 7.34 & 52.33 & 21.23 & 5.23 \\
\hline $148-4-3$ & 31.0 & $\mathrm{CS}$ & 19.58 & 8.45 & 7.44 & 51.63 & 21.86 & 5.02 \\
\hline $148-5-2$ & 39.0 & $\mathrm{CS}$ & 19.57 & 8.18 & 6.75 & 50.82 & 16.34 & 6.26 \\
\hline $148-6-4$ & 51.0 & CS & 19.54 & 7.86 & 6.63 & 50.60 & 16.76 & 6.47 \\
\hline $148-7-3$ & 59.0 & CS & 19.59 & 7.67 & 5.82 & 47.66 & 12.80 & 7.61 \\
\hline $148-8-3$ & 67.0 & CS & 19.59 & 6.80 & 5.45 & 47.20 & 10.09 & 7.66 \\
\hline $148-9-4$ & 79.0 & $\mathrm{CS}$ & 19.49 & 6.90 & 5.23 & 44.58 & 8.22 & 7.71 \\
\hline $148-10-3$ & 86.0 & $\mathrm{CS}$ & 19.48 & 6.71 & 5.17 & 45.24 & 9.99 & 6.72 \\
\hline $148-12-4$ & 106.0 & $\mathrm{CS}$ & 19.40 & 5.88 & 6.05 & 38.41 & 0.00 & 5.27 \\
\hline $148-14-3$ & 122.0 & CS & 19.41 & 5.98 & 6.66 & 40.49 & 6.55 & 4.82 \\
\hline $148-16-3$ & 141.0 & CS & 19.26 & 5.52 & 7.41 & 36.66 & 3.01 & 3.67 \\
\hline $148-18-2$ & 159.0 & CS & 19.38 & 5.37 & 8.75 & 35.95 & 3.01 & 3.73 \\
\hline $148-20-3$ & 179.0 & $\mathrm{CS}$ & 19.23 & 5.37 & 9.43 & 34.65 & 0.00 & 3.63 \\
\hline $148-23-4$ & 209.0 & CS & 19.49 & 5.62 & 9.82 & 35.86 & 3.22 & 3.05 \\
\hline $148-26-2$ & 232.0 & $\mathrm{CS}$ & 19.39 & 5.88 & 9.54 & 36.72 & 4.26 & 2.36 \\
\hline $149-2-2$ & 4.0 & $\mathrm{CS}$ & 19.38 & 9.46 & 10.26 & 53.63 & 27.80 & 2.29 \\
\hline $149-2-5$ & 8.0 & CS & 19.45 & 9.65 & 10.55 & 53.15 & 27.69 & 2.38 \\
\hline $149-3-5$ & 17.0 & $\mathrm{CS}$ & 19.50 & 9.75 & 11.60 & 50.16 & 27.27 & 2.59 \\
\hline $149-4-3$ & 23.0 & $\mathrm{CS}$ & 19.55 & 8.95 & 11.76 & 52.33 & 25.71 & 2.44 \\
\hline $149-5-3$ & 32.0 & CS & 19.62 & 8.86 & 12.97 & 50.39 & 26.96 & 2.44 \\
\hline $149-6-4$ & 43.0 & $\mathrm{CS}$ & 19.65 & 8.32 & 13.43 & 49.56 & 25.40 & 2.09 \\
\hline $149-7-2$ & 49.0 & CS & 19.63 & 8.46 & 13.05 & 49.52 & 26.23 & 2.19 \\
\hline $149-8-4$ & 62.0 & $\mathrm{CS}$ & 19.61 & 7.92 & 13.68 & 50.06 & 26.12 & 2.06 \\
\hline $149-9-5$ & 72.0 & $\mathrm{CS}$ & 19.65 & 7.51 & 15.25 & 48.96 & 25.08 & 1.79 \\
\hline $149-10-2$ & 78.0 & $\mathrm{CS}$ & 19.51 & 7.09 & 16.16 & 48.52 & 25.92 & 1.77 \\
\hline $149-11-4$ & 90.0 & CS & 19.29 & 6.98 & 16.40 & 48.49 & 23.73 & 1.71 \\
\hline $149-12-5$ & 100.0 & CS & 17.14 & 5.72 & 17.33 & 36.98 & 21.23 & 1.29 \\
\hline $149-14-3$ & 116.0 & $\mathrm{CS}$ & 19.45 & 5.84 & 20.55 & 45.15 & 24.15 & 1.77 \\
\hline $149-16-4$ & 135.0 & CS & 19.53 & 5.54 & 22.26 & 41.48 & 22.17 & 1.81 \\
\hline $149-18-3$ & 153.0 & CS & 19.74 & 6.76 & 21.97 & 41.43 & 22.48 & 2.20 \\
\hline $149-20-4$ & 173.0 & CS & 19.87 & 6.18 & 26.12 & 36.67 & 23.11 & 3.03 \\
\hline $149-23-4$ & 201.0 & CS & 19.85 & 5.94 & 27.27 & 35.39 & 21.86 & 3.21 \\
\hline $149-26-2$ & 226.0 & CS & 19.86 & 5.78 & 27.83 & 34.44 & 21.75 & 2.91 \\
\hline $149-29-3$ & 254.0 & CS & 19.91 & 5.60 & 31.83 & 33.66 & 21.75 & 2.92 \\
\hline $149-31-1$ & 271.0 & CS & 20.09 & 5.81 & 31.76 & 33.00 & 22.59 & 3.30 \\
\hline $149-33-1$ & 289.0 & CS & 20.18 & 5.88 & 32.86 & 32.25 & 24.25 & 3.00 \\
\hline $149-35-4$ & 313.0 & CS & 20.04 & 5.40 & 29.88 & 34.02 & 22.38 & 2.54 \\
\hline $149-37-3$ & 329.0 & CS & 20.09 & 5.23 & 31.10 & 33.73 & 21.96 & 2.46 \\
\hline $149-40-1$ & 354.0 & $\mathrm{CS}$ & 19.50 & 4.73 & 30.56 & 32.45 & 21.13 & 2.43 \\
\hline $149-41-5$ & 369.0 & $\mathrm{CS}$ & 20.11 & 4.88 & 30.22 & 33.85 & 20.92 & 2.27 \\
\hline $149-42-2$ & 374.0 & CS & 20.14 & 4.76 & 31.39 & 33.24 & 22.27 & 2.44 \\
\hline $147 \mathrm{~B}-1-2$ & 2.5 & WS & 20.00 & 9.97 & 5.86 & 46.89 & 24.15 & 14.57 \\
\hline $147 \mathrm{~B}-1-3$ & 4.2 & WS & 19.83 & 9.46 & 3.56 & 44.42 & 5.41 & 17.71 \\
\hline
\end{tabular}


TABLE 1 - Continued

\begin{tabular}{|c|c|c|c|c|c|c|c|c|}
\hline Sample & Depth & Type & $\mathrm{Cl}$ & $\mathrm{K}$ & $\mathrm{Ca}$ & $\mathrm{Mg}$ & $\mathrm{SO}_{4}$ & Alk. \\
\hline $147 \mathrm{~B}-1-4$ & 4.7 & WS & 19.93 & 8.69 & 1.98 & 44.42 & 2.70 & 17.60 \\
\hline $147 \mathrm{~B}-1-4$ & 4.8 & WS & 19.79 & 9.20 & 1.97 & 42.66 & 1.35 & 17.69 \\
\hline 147B-1-4 & 5.1 & WS & 20.02 & 8.69 & 1.72 & 43.19 & 0.20 & 15.17 \\
\hline $147 \mathrm{~B}-2-3 / 4$ & 8.5 & WS & 0.00 & 0.00 & 0.00 & 0.00 & 0.00 & 0.00 \\
\hline $147 \mathrm{~B}-2-2$ & 15.0 & WS & 20.00 & 9.97 & 9.25 & 54.53 & 23.94 & 7.90 \\
\hline $147 \mathrm{~B}-2-6$ & 21.0 & WS & 20.09 & 8.69 & 4.09 & 39.98 & 0.41 & 14.22 \\
\hline $147 \mathrm{~B}-4-3 / 4$ & 28.00 & WS & 0.00 & 0.00 & 0.00 & 0.00 & 0.00 & 0.00 \\
\hline $147 \mathrm{~B}-6-2$ & 51.0 & WS & 19.66 & 9.97 & 3.58 & 27.56 & 0.31 & 10.06 \\
\hline $147 \mathrm{~B}-8-2 / 3$ & 63.0 & WS & 0.00 & 0.00 & 0.00 & 0.00 & 0.00 & 0.00 \\
\hline $147 \mathrm{~B}-7-4$ & 63.0 & WS & 18.95 & 10.74 & 5.23 & 26.73 & 0.31 & 24.64 \\
\hline $147 \mathrm{~B}-9-4$ & 83.0 & WS & 18.72 & 9.71 & 5.61 & 25.58 & 0.10 & 29.14 \\
\hline $147-10-3 / 4$ & 82.0 & WS & 0.00 & 0.00 & 0.00 & 0.00 & 0.00 & 0.00 \\
\hline 147B-11-3 & 100.0 & WS & 18.53 & 9.84 & 5.85 & 25.91 & 1.87 & 34.23 \\
\hline $147 C-2-1$ & 126.0 & WS & 18.21 & 9.20 & 6.00 & 26.73 & 1.76 & 32.89 \\
\hline $147 C-4-4$ & 148.0 & WS & 18.14 & 9.46 & 5.81 & 23.68 & 1.50 & 30.80 \\
\hline $147 C-7-4$ & 176.0 & WS & 17.79 & 8.18 & 6.15 & 22.21 & 0.62 & 23.74 \\
\hline $148-1-2$ & 3.0 & WS & 19.73 & 11.76 & 9.33 & 49.70 & 27.37 & 3.39 \\
\hline $148-1-4$ & 6.0 & WS & 19.42 & 11.25 & 8.09 & 50.58 & 25.92 & 4.16 \\
\hline $148-2-1$ & 11.0 & WS & 19.43 & 12.27 & 7.15 & 48.53 & 24.46 & 3.33 \\
\hline $148-2-3$ & 13.0 & WS & 19.53 & 11.25 & 7.21 & 48.63 & 23.11 & 4.76 \\
\hline $148-3-3$ & 22.0 & WS & 19.61 & 10.48 & 7.10 & 49.43 & 22.06 & 5.37 \\
\hline $148-4-3$ & 31.0 & WS & 19.61 & 10.74 & 7.33 & 50.16 & 23.21 & 4.76 \\
\hline $148-5-2$ & 39.0 & WS & 19.59 & 9.20 & 5.76 & 48.23 & 16.65 & 6.26 \\
\hline $148-6-4$ & 51.0 & WS & 19.64 & 10.23 & 6.01 & 46.47 & 18.11 & 6.05 \\
\hline $148-7-3$ & 59.0 & WS & 19.56 & 9.20 & 5.38 & 43.47 & 11.76 & 7.56 \\
\hline $148-8-3$ & 67.0 & WS & 19.57 & 8.95 & 5.12 & 41.64 & 9.99 & 8.08 \\
\hline $148-9-4$ & 79.0 & WS & 19.50 & 8.98 & 4.95 & 40.92 & 8.53 & 7.79 \\
\hline $148-10-3$ & 86.0 & WS & 19.60 & 8.95 & 5.02 & 40.22 & 8.95 & 6.90 \\
\hline $148-12-4$ & 106.0 & WS & 19.50 & 8.10 & 5.59 & 35.25 & 7.30 & 5.62 \\
\hline $148-14-3$ & 122.0 & WS & 19.46 & 7.41 & 5.90 & 35.36 & 4.78 & 5.18 \\
\hline $148-16-3$ & 141.0 & WS & 19.53 & 7.16 & 6.50 & 32.90 & 3.43 & 3.67 \\
\hline $148-18-2$ & 159.0 & WS & 19.48 & 6.64 & 7.12 & 32.85 & 2.91 & 3.99 \\
\hline $148-20-3$ & 179.0 & WS & 19.50 & 6.90 & 8.78 & 32.10 & 6.45 & 3.72 \\
\hline $148-23-4$ & 209.0 & WS & 19.45 & 7.41 & 9.72 & 32.27 & 0.00 & 3.03 \\
\hline $148-26-2$ & 232.0 & wS & 19.46 & 7.16 & 9.10 & 33.90 & 3.95 & 2.96 \\
\hline $149-2-2$ & 4.0 & WS & 19.46 & 10.74 & 10.03 & 50.84 & 28.41 & 2.44 \\
\hline $149-2-5$ & 8.0 & WS & 19.45 & 10.50 & 10.20 & 51.75 & 28.20 & 2.54 \\
\hline $149-3-5$ & 17.0 & WS & 19.42 & 10.25 & 11.61 & 51.21 & 28.00 & 2.76 \\
\hline $149-4-3$ & 23.0 & WS & 19.58 & 9.97 & 11.64 & 50.57 & 27.48 & 2.72 \\
\hline $149-5-3$ & 32.0 & WS & 19.67 & 10.23 & 12.70 & 48.58 & 24.15 & 2.57 \\
\hline $149-6-4$ & 43.0 & WS & 19.63 & 9.71 & 13.72 & 47.30 & 26. & 2.33 \\
\hline $149-7-2$ & 49.0 & WS & 19.60 & 9.71 & 12.99 & 48.53 & 27.17 & 2.37 \\
\hline $149-8-4$ & 62.0 & WS & 19.66 & 9.46 & 13.65 & 47.83 & 27.58 & 2.30 \\
\hline $149-9-5$ & 72.0 & WS & 19.61 & 8.95 & 14.76 & 46.53 & 25.92 & 2.06 \\
\hline $149-10-2$ & 78.0 & WS & 19.65 & 7.92 & 16.09 & 45.54 & 25.92 & 1.94 \\
\hline $149-11-4$ & 90.0 & WS & 19.49 & 8.43 & 15.99 & 45.08 & 25.92 & 1.79 \\
\hline $149-12-5$ & 100.0 & WS & 17.36 & 7.16 & 16.33 & 36.73 & 22.17 & 1.29 \\
\hline $149-14-3$ & 116.0 & WS & 19.54 & 7.67 & 19.70 & 41.23 & 25.71 & 1.93 \\
\hline $149-16-4$ & 135.0 & WS & 19.96 & 7.67 & 21.99 & 39.26 & 22.27 & 2.32 \\
\hline $149-18-3$ & 153.0 & WS & 19.73 & 7.67 & 21.72 & 40.12 & 23.42 & 2.29 \\
\hline $149-20-4$ & 173.0 & WS & 19.84 & 7.92 & 25.39 & 35.23 & 24.15 & 3.00 \\
\hline $149-23-4$ & 201.0 & WS & 19.83 & 6.90 & 26.97 & 33.31 & 22.06 & 3.45 \\
\hline $149-26-2$ & 226.0 & WS & 19.95 & 6.64 & 27.92 & 32.99 & 23.11 & 2.97 \\
\hline $149-29-3$ & 254.0 & WS & 19.99 & 7.16 & 29.10 & 32.60 & 21.02 & 2.75 \\
\hline $149-31-1$ & 271.0 & WS & 20.11 & 6.64 & 19.49 & 32.08 & 23.21 & 3.29 \\
\hline 149-33-1 & 289.0 & WS & 20.10 & & 30.66 & & & 2.42 \\
\hline $149-37-3$ & 329.0 & WS & 20.14 & 5.62 & 30.37 & 32.64 & 23.63 & 2.48 \\
\hline $149-40-1$ & 354.0 & WS & 19.34 & 5.37 & 29.91 & 32.13 & 22.48 & 2.39 \\
\hline $149-41-5$ & 369.0 & WS & 20.07 & 6.13 & 30.37 & 35.09 & 23.73 & 2.22 \\
\hline $149-42-2$ & 374.0 & WS & 20.10 & 5.62 & 29.88 & 34.67 & 22.69 & 2.30 \\
\hline
\end{tabular}

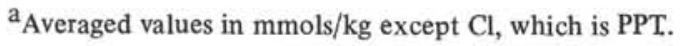




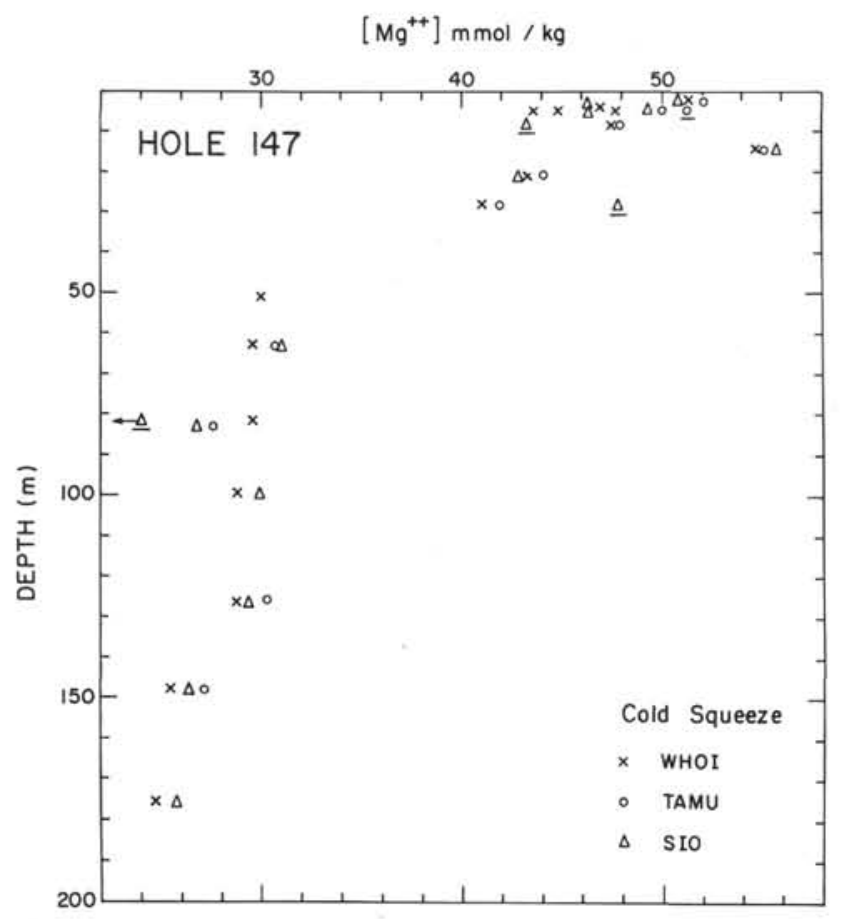

Figure 1. Site 147 magnesium profile (cold squeeze). Underlined data are considered inaccurate.

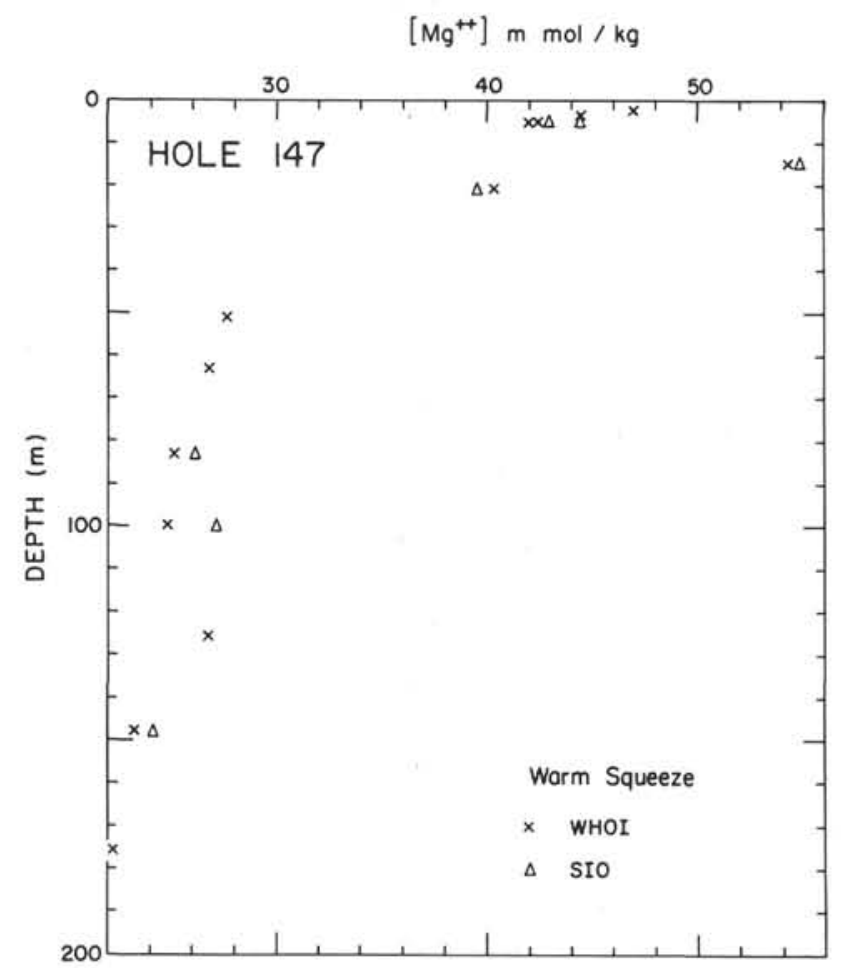

Figure 2. Site 147 magnesium profile (warm squeeze).

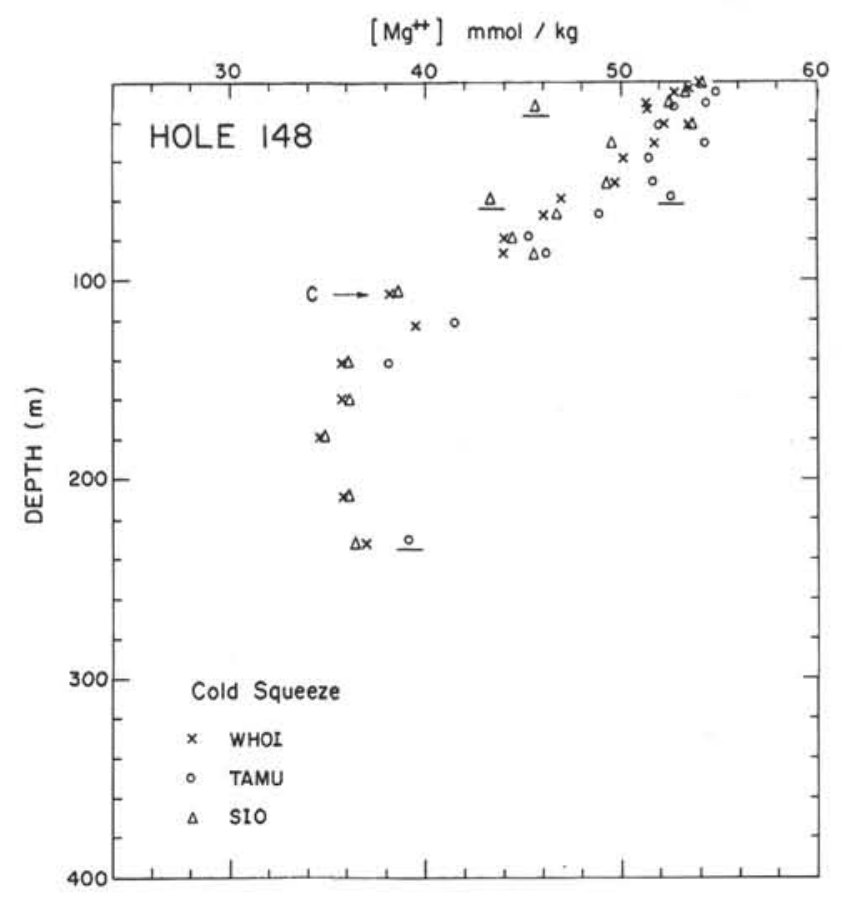

Figure 3. Site 148 magnesium profile (cold squeeze). Underlined data are considered inaccurate; $C=$ fresh water contamination during drilling.

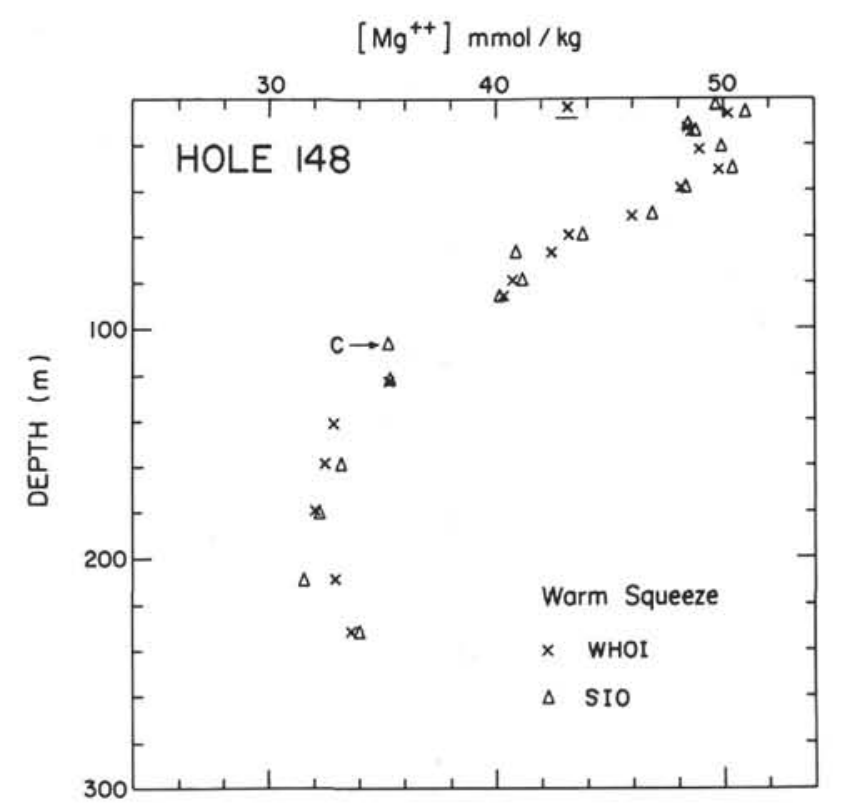

Figure 4. Site 148 magnesium profile (warm squeeze). Underlined data are considered inaccurate; $C=$ contamination with fresh water during drilling. 


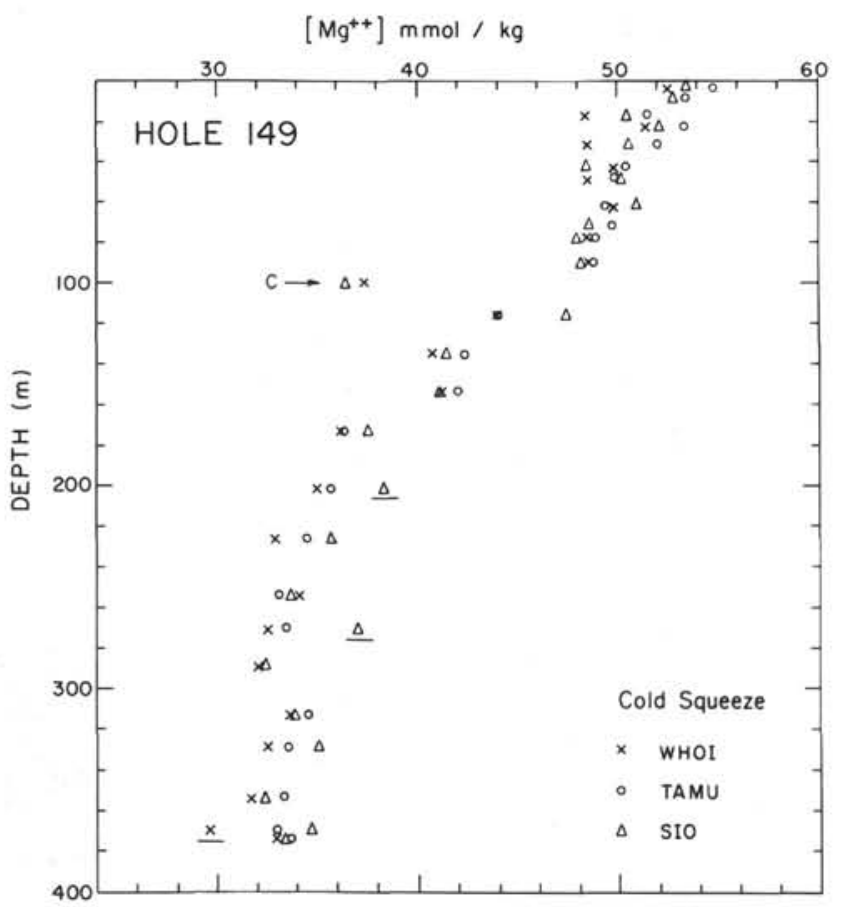

Figure 5. Site 149 magnesium profile (cold squeeze). Underlined data are considered inaccurate; $C=$ contamination with dye during drilling.

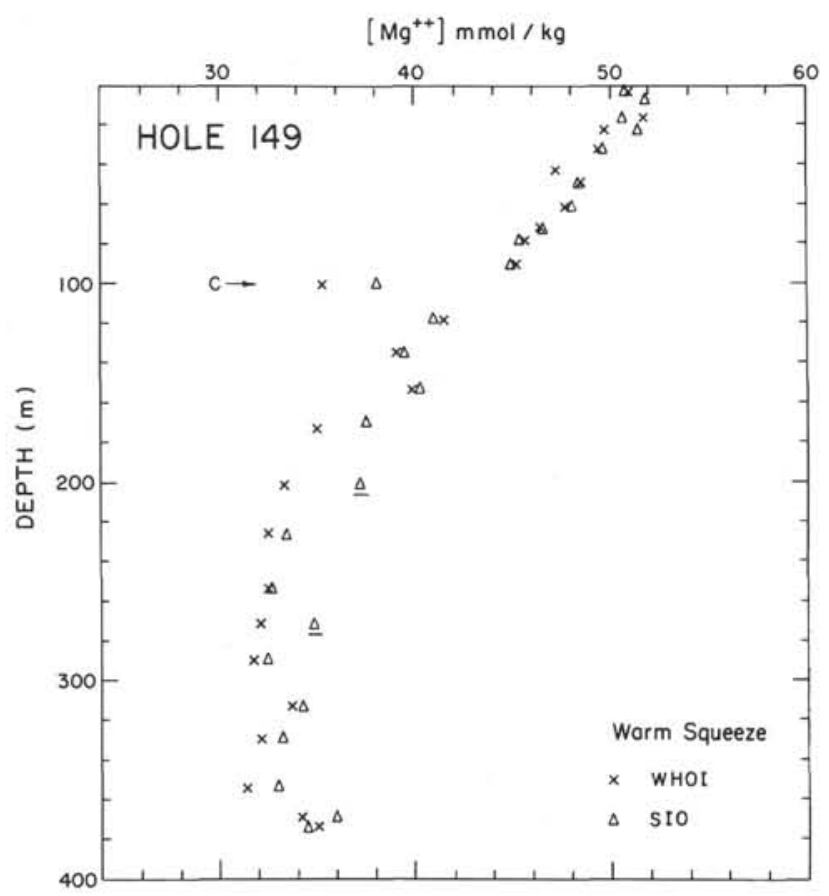

Figure 6. Site 149 magnesium profile (warm squeeze). Underlined data are considered inaccurate; $C=$ contamination with dye during drilling.
$\mathrm{SO}_{4}=$

TAMU and WHOI both determined $\mathrm{SO}_{4}=$ microgravimetrically. Agreement is generally within $\pm 0.8 \mathrm{mmol} / \mathrm{kg}$ or $\pm 6 \%$ (34/49), whichever is larger. There is a tendency for the TAMU values to be a few percent larger than the WHOI values. Nine samples were analyzed by Cescon and Machi (this volume) by using a cation exchange column and $\mathrm{BaCl}_{2}$ titration. Their values agree with the WHOI results within $\pm 0.3 \mathrm{mmol} / \mathrm{kg}$ or $\pm 2 \%(7 / 9)$, and with the TAMU data within $\pm 0.8 \mathrm{mmol} / \mathrm{kg}$ or $\pm 8 \%(3 / 5)$. On this basis, the WHOI sulfate data is chosen as slightly more reliable than the TAMU data.

$\mathrm{Na}^{+}$

The TAMU and WHOI sodium analyses were both done by atomic absorption and generally agree within $\pm 1.5 \%$. Since $\left[\mathrm{Na}^{+}\right]$differences between pore water and seawater are less than the analytical uncertainties, calculations in this paper assume that pore water has the same $\mathrm{Na}: \mathrm{Cl}$ ratio as seawater.

$\mathrm{K}^{+}$

Both investigators measured potassium by atomic absorption. The two sets of data agree within $\pm 5 \%(26 / 38)$, although the TAMU values are systematically about $2 \%$ greater than the WHOI values. Neither set of data appears superior, so the two are averaged unless two analyses differ by more than $10 \%$, and one of these clearly departs from the trend with depth (3 samples). One WS analysis (149-3-5) appears anomalously low and is replaced by an interpolated value.

$\mathrm{Mg}^{++}$

TAMU and WHOI both determined $\left[\mathrm{Mg}^{++}\right]$by atomic absorption while SIO measured the difference between an EDTA titration of total alkali earths and an EGTA titration of calcium only, applying a small correction for strontium content. The two sets of atomic absorption data bracket the titration data, with the TAMU results systematically about $2 \%$ greater and the WHOI results systematically about $1 \%$ less than the SIO results. $\left[\mathrm{Mg}^{++}\right]$listed in Table 1 is an average of all analyses except values which differ from the average by more than $5 \%$ and show a claer deviation from the trend with depth $(1 / 108$ for WHOI, $3 / 49$ for TAMU, 9/106 for SIO). Generally, each investigator's results fall within $\pm 2.5 \%$ of this average ( $91 / 108$ for WHOI, $37 / 49$ for TAMU, 87/106 for SIO).

$\mathrm{Ca}^{++}$

TAMU and WHOI determined $\left[\mathrm{Ca}^{++}\right]$by atomic absorption and SIO by titration with EGTA. The SIO samples were acidified during storage, and it has been suggested (Gieskes, this volume) that $\mathrm{CaCO}_{3}$ precipitation may have occurred in unacidified TAMU and WHOI samples from below 63 meters at Site 147, causing these atomic absorption analyses to be anomalously low. Therefore, for 


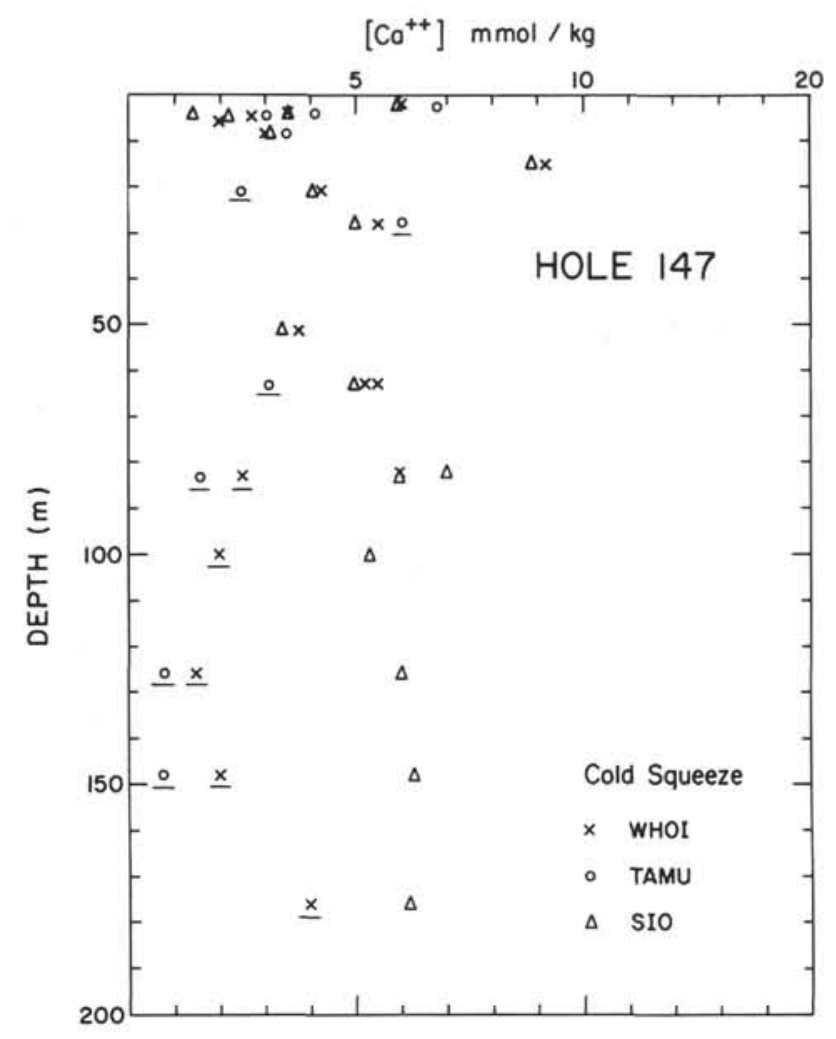

Figure 7. Site 147 calcium profile (cold squeeze). Underlined data are considered inaccurate.

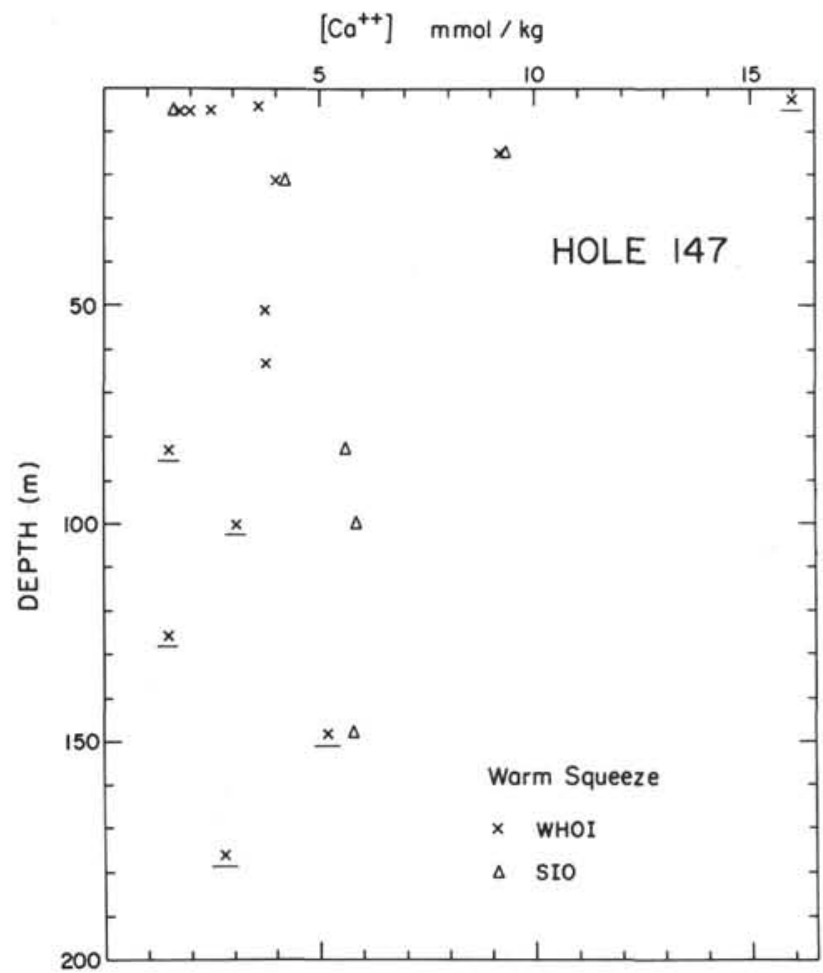

Figure 8. Site 147 calcium profile (warm squeeze). Underlined data are considered inaccurate. these samples, the SIO results are accepted as more reliable. If no WS titration result for calcium was reported, it is assumed equal to the CS calcium titration. At Sites 148 and 149 , the WHOI results show a slightly smoother profile than the SIO results, but are systematically higher, a discrepancy which increases with depth. The TAMU results are in slightly better agreement with the SIO results but appear to be less precise and also tend to be greater than the titration values.

Since titration and atomic absorption results for magnesium generally agreed within $\pm 1.0 \mathrm{mmol} / \mathrm{kg}$, titration calcium should be equally reliable. However, the WHOI $\left[\mathrm{Ca}^{++}\right]$measurements on samples below 160 meters at Site 149 average about $4 \mathrm{mmol} / \mathrm{kg}$ greater than the SIO results. Below 130 meters at Site 148 and between 100 and 160 meters at Site 149 , they are about $1.5 \mathrm{mmol} / \mathrm{kg}$ greater. A similar, although smaller, discrepancy exists between the TAMU and SIO results in the same regions. The depth dependence of this discrepancy suggests that it might be associated with the matrix effect difference between pore water and the seawater standards used in atomic absorption analyses. The atomic absorption measurements from these regions are judged unreliable.

To check the SIO results which appear to deviate from the trend with depth, the titration magnesium for these samples was compared to the atomic absorption magnesium. Complementary calcium and magnesium discrepancies greater than $\pm 1.0 \mathrm{mmol} / \mathrm{kg}$ were assumed to represent calcium titration errors, and the titration calcium was adjusted to remove this (3/14 CS values and $3 / 14 \mathrm{WS}$ values, all at Site 149). The WS titration value at 141 meters at Site 148 is interpolated.

For all other samples, Table 1 lists an average of all reported analyses except those which clearly depart from the trend with depth and disagree with the average of the other two by $\pm 0.5 \mathrm{mmol} / \mathrm{kg}$ or $\pm 5 \%$, whichever was larger (1/70 for WHOI, $10 / 29$ for TAMU, $1 / 63$ for SIO). Individual analyses generally agree with the average within $\pm 0.25 \mathrm{mmol} / \mathrm{kg}$ or $2.5 \%$ ( $48 / 63$ for WHOI, $41 / 61$ for SIO, $10 / 25$ for TAMU), with the TAMU data from Sites 147 and 148 being systematically about $0.6 \mathrm{mmol} / \mathrm{kg}$ greater than the average of all three.

\section{DETERMINATION OF CONSTANTS FOR THE CARBONATE SYSTEM IN PORE WATERS}

The carbonate parameters $\Sigma \mathrm{CO}_{2}$, carbonate alkalinity, $p \mathrm{H}, p_{\mathrm{CO}_{2}}$, and $\left[\mathrm{CO}_{3}{ }^{ }\right]$compose a system which may be defined by a knowledge of any two of these parameters, the first and second apparent dissociation constants of carbonic acid for the system $K_{1}^{\prime}$ and $K_{2}^{\prime}$, and the solubility of $\mathrm{CO}_{2}$, $\alpha$. The apparent constants $K_{1}^{\prime}$ and $K_{2}^{\prime}$ are defined by

$$
\begin{gathered}
K_{1}^{\prime}=\frac{a_{\mathrm{H}}+\left[\mathrm{HCO}_{3}{ }^{-}\right]}{\alpha p_{\mathrm{CO}_{2}}} \\
K_{2}^{\prime}=\frac{a_{\mathrm{H}^{+}}\left[\mathrm{CO}_{3}{ }^{-}\right]}{\left[\mathrm{HCO}_{3}{ }^{-}\right]}
\end{gathered}
$$




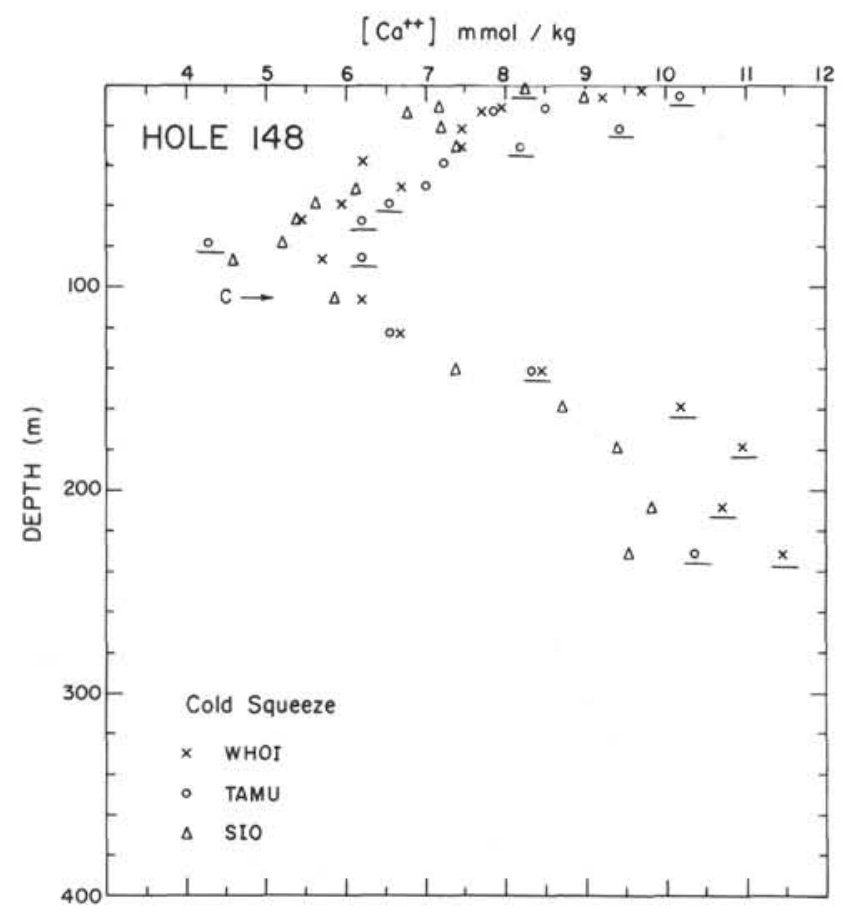

Figure 9. Site 148 calcium profile (cold squeeze). Underlined data are considered inaccurate; $C=$ contamination with fresh water during drilling.

These may be related to the thermodynamic constants

$$
\begin{aligned}
& K_{1}^{\mathrm{o}}=\frac{a_{\mathrm{H}^{+}}+a_{\mathrm{HCO}_{3}}{ }^{-}}{a_{\mathrm{H}_{2} \mathrm{O}^{a} \mathrm{CO}_{2}}} \\
& K_{2}^{\circ}=\frac{a_{\mathrm{H}}+a \mathrm{CO}_{3}}{a_{\mathrm{HCO}_{3}}{ }^{-}}
\end{aligned}
$$

by the expressions

$$
\begin{gathered}
K_{1}^{\prime}=\frac{a_{\mathrm{H}_{2} \mathrm{O} \gamma_{\mathrm{CO}_{2}}}}{\gamma_{\mathrm{HCO}_{3}^{-}}} \mathrm{K}_{1}^{\circ} \\
K_{2}^{\prime}=\frac{\gamma_{\mathrm{HCO}_{3}^{-}}}{\gamma_{\mathrm{CO}_{3}}=} \mathrm{K}_{2}^{\circ}
\end{gathered}
$$

where $\gamma_{i}$ is the activity coefficient of species $i$ chosen so that $a_{i}=\gamma_{i}[i]$. Estimation of these activity coefficients poses a difficult problem since they are functions of both ionic strength and solution composition.

Lyman (1957) has empirically determined $K_{2}^{\prime}$ and $K_{2}^{\prime}$ for solutions of artificial seawater. Data from the GEOSECS I cruise (Takahashi et al., 1970) suggest that Lyman's $K_{1}^{\prime}$ is accurate to $2 \%$ or better and Simpson's (1970) data indicate that near $25^{\circ} \mathrm{C}$, Lyman's ratio of $K_{1}^{\prime} / K_{2}^{\prime}$ is accurate to $10 \%$. $\alpha$ has been determined to better than $1 \%$ in salt solutions (Bohr, 1899; Harned and Davis,
1943) and in seawater (Krough, 1904; Li and Tsui, 1971). Calculations of $K_{1}^{\prime}$ and $K_{2}^{\prime}$ for seawater from thermodynamic principles by Garrels and Thompson (1962), Berner (1965), and others have been less successful. Therefore, since pore water is often similar in composition to seawater, the approach adopted here is to adjust Lyman's empirical seawater constants for the differences in $\left[\mathrm{Ca}^{++}\right],\left[\mathrm{Mg}^{++}\right],\left[\mathrm{SO}_{4}{ }^{\circ}\right]$, and $\left[\mathrm{HCO}_{3}{ }^{-}\right]$observed between pore water and seawater. A model for apparent constant estimation (MACE) is discussed in the following paragraphs.

The major difficulty in calculating the activity coefficients of interest is a result of the imprecise knowledge of the nature and magnitude of complex ion formation in seawater. Garrels and Thompson (1962) proposed a model for major ion complexing in seawater which may be used as a first approximation to the real system. Using their model and the major element composition listed in Table 1, a computer program was written to calculate the ratios

$$
f_{i}=\frac{\text { uncomplexed fraction in seawater }}{\text { uncomplexed fraction in pore water }}
$$

for the $\left[\mathrm{HCO}_{3}{ }^{-}\right],\left[\mathrm{CO}_{3}{ }^{=}\right]$, and $\left[\mathrm{Ca}^{++}\right]$in each pore water sample. Since pore water and seawater of the same chlorinity should have nearly the same ionic strength, the only difference between the activity coefficients of these ions in seawater and in pore water of the same chlorinity should be due to the differences in the uncomplexed fractions, $f_{i}$. Assuming $\gamma_{\mathrm{CO}_{2}}$ and $a_{\mathrm{H}_{2} \mathrm{O}}$ depend only on chlorinity and letting

$$
\begin{aligned}
& \gamma_{i}=\text { activity coefficient of } i \text { in seawater } \\
& \gamma_{i}=\text { activity coefficient of } i \text { in pore water } \\
& K_{1}^{\prime}=\frac{a_{\mathrm{H}_{2} \mathrm{O}^{\prime} \gamma_{\mathrm{CO}_{2}}^{\prime}}^{\gamma_{\mathrm{HCO}_{3}}-}}{{ }^{\mathrm{O}}}=\frac{\gamma_{1} \mathrm{HCO}_{3}{ }^{-}}{\gamma_{\mathrm{HCO}_{3}}{ }^{-}} K_{1}^{S}=\left(f_{\mathrm{HCO}_{3}}-\right) K_{1}^{S}
\end{aligned}
$$

$$
K_{2}^{\prime}=\frac{\gamma_{\mathrm{HCO}_{3}}^{\prime}}{\gamma_{\mathrm{CO}_{3}}^{\prime}=} K_{2}^{\mathrm{o}}=\frac{\gamma_{\mathrm{HCO}_{3}}^{\prime}-\gamma_{\mathrm{CO}_{3}}=}{\gamma_{\mathrm{HCO}_{3}}{ }^{-} f_{\mathrm{CO}_{3}}=} K_{2}^{S}=\frac{f_{\mathrm{CO}_{3}}}{f_{\mathrm{HCO}_{3}}} K_{2}^{S}
$$

where the superscript $S$ denotes an empirical seawater constant.

The same approach can be used to estimate the apparent solubility product of calcite

$$
K_{s p}^{\prime}=\left[\mathrm{Ca}^{++}\right]\left[\mathrm{CO}_{3}{ }^{=}\right]
$$

and the first apparent dissociation constant of boric acid

$$
K_{\mathrm{B}}^{\prime}=\frac{a_{\mathrm{H}}+\left[\mathrm{B}(\mathrm{OH})_{4}^{-}\right]}{\left[\mathrm{H}_{3} \mathrm{BO}_{3} \cdot \mathrm{H}_{2} \mathrm{O}\right]}
$$




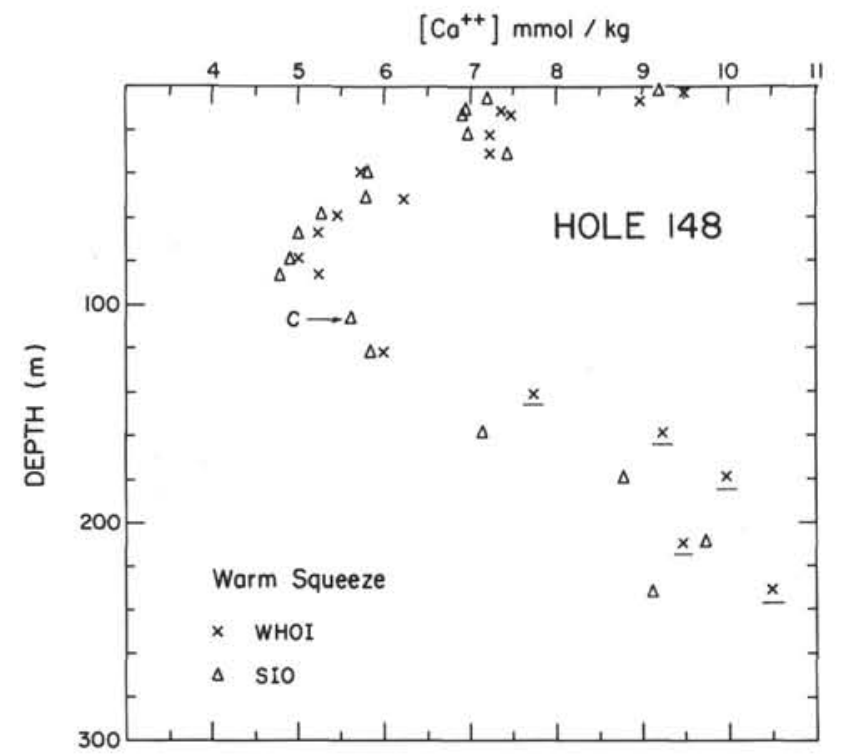

Figure 10. Site 148 calcium profile (warm squeeze). Underlined data are considered inaccurate; $C=$ contamination with fresh water during drilling.

Assuming that the complexing of $\left[\mathrm{B}(\mathrm{OH})_{4}{ }^{-}\right]$is similar to $\left[\mathrm{HCO}_{3}{ }^{-}\right]$, these constants become

$$
\begin{gathered}
K_{s p}^{\prime}=f_{\mathrm{Ca}^{++}} \times f_{\mathrm{CO}_{3}}=\times \mathrm{K}_{s p}^{S} \\
K_{\mathrm{B}}^{\prime}=f_{\mathrm{HCO}_{3}}-\times \mathrm{K}_{B}^{S}
\end{gathered}
$$

Expressions to compute apparent constants for seawater are listed in Table 2a. The temperature and chloronity dependence for $K_{1}^{S}, K_{2}^{S}$, and $K_{B}^{S}$ is from a least squares fit to Lyman's (1957) data. $\alpha, K_{s p}^{S}$, and the pressure dependence of the apparent constants are taken from relations given by $\mathrm{Li}$ et al. (1969) which were based on experimental data from Bohr (1899) and Harned and Davis (1943) as recalculated by Buch (1951), from MacIntyre (1965), and from Disteche and Disteche (1967), respectively.

The effect of MACE is illustrated in Table 2b. The ratio of pore water constants to seawater constants is shown for several varieties of pore water $\left(19^{\circ} \%\right.$ c chlorinity, $\left.25^{\circ} \mathrm{C}\right)$, including the extremes of chemistry exhibited by samples considered in this paper. The only compositional changes to which the apparent constants show marked sensitivity are variations in $\left[\mathrm{Mg}^{++}\right]$. Site 149 , where $\left[\mathrm{Mg}^{++}\right]$decreases by a factor of 2 , should provide a test for the validity of this model. This will be discussed in a later section.

\section{ALKALINITY}

In these cores, the ionic species which can contribute to total alkalinity determinations are $\left[\mathrm{H}_{3} \mathrm{SiO}_{4}{ }^{-}\right],\left[\mathrm{PO}_{4}{ }^{\equiv}\right]$, $\left[\mathrm{HPO}_{4}{ }^{=}\right],\left[\mathrm{H}_{2} \mathrm{PO}_{4}^{-}\right],\left[\mathrm{B}(\mathrm{OH})_{4}^{-}\right],\left[\mathrm{HCO}_{3}{ }^{-}\right]$, and $\left[\mathrm{CO}_{3}=\right]$. Table $3 \mathrm{a}$ indicates the abundance of each species at $p \mathrm{H} 7.0$ and 8.0 as a fraction of the total inorganic

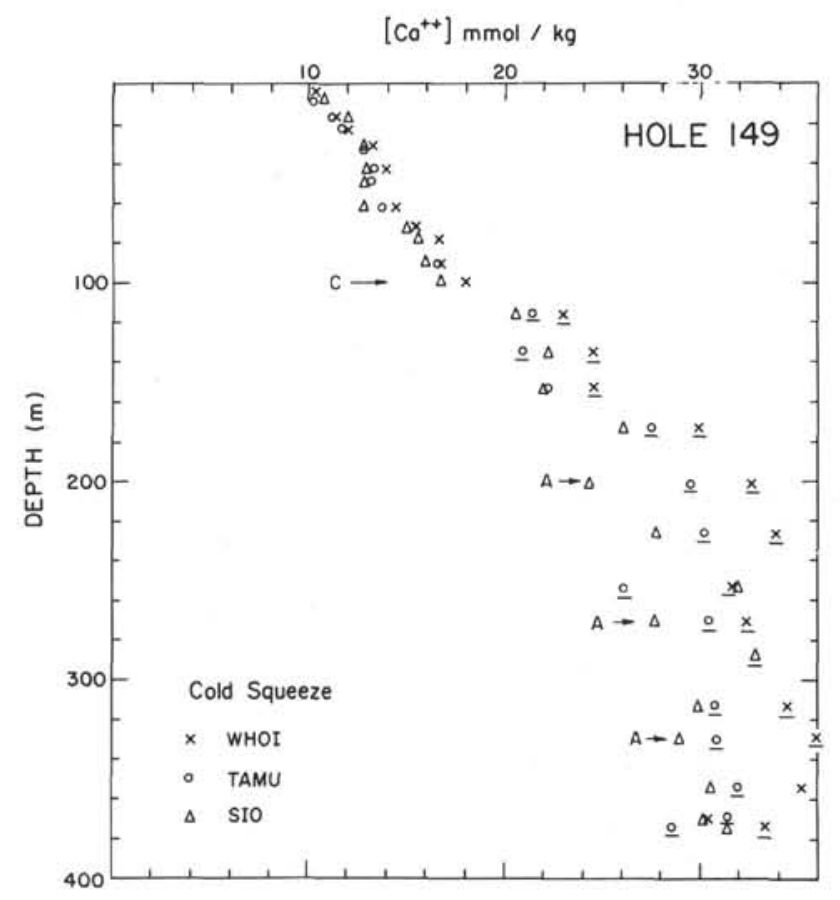

Figure 11. Site 149 calcium profile (cold squeeze). Underlined data are considered inaccurate; $C=$ contamination with dye during drilling; $A=$ calcium titration result considered low since it is accompanied by a complementary magnesium anomaly.

elemental abundance, calculated from the apparent dissociation constants for seawater listed in Table $3 \mathrm{~b}$. An alkalinity titration converts all of these to undissociated species, except phosphate anions, which become primarily $\left[\mathrm{H}_{2} \mathrm{PO}_{4}-\right]$. Therefore, for pore water of $p \mathrm{H} 8$, alkalinity could be expressed as

$$
\Sigma \mathrm{A}=0.04 \times \Sigma \mathrm{Si}+1.2 \times \Sigma \mathrm{P}+0.16 \times \Sigma \mathrm{B}+1.06 \times \Sigma \mathrm{C}
$$

and for pore water of $p \mathrm{H} 7$,

$$
\Sigma \mathrm{A}=0.83 \times \Sigma \mathrm{P}+0.02 \times \Sigma \mathrm{B}+0.92 \times \Sigma \mathrm{C}
$$

The silica, phosphate (Gieskes, this volume), and borate (Presley et al., this volume) data may be compared to the alkalinity data (Table 1). The above equations clearly indicate that, in the observed $p \mathrm{H}$ range (Table 5), the first two species contribute 0 to $0.5 \%$ and borate contributes 0.5 to $1.0 \%$, while carbonate species contribute 99 to $100 \%$ of the total.

Gieskes (this volume), using a modified Gran titration, measured alkalinity on shipboard. His results (Table 1) are plotted in Figures 13 to 15 . He estimates their accuracy as $\pm 0.5 \%$. To check their reliability, they can be compared (Table 4) with the $\Sigma \mathrm{A}$ calculated from the $\Sigma \mathrm{CO}_{2}$ and $p_{\mathrm{CO}_{2}}$ results of Takahashi and Prince (Queens College, this volume), $\Sigma$ B (TAMU), and $\Sigma \mathrm{Si}$ and $\Sigma \mathrm{P}$ (SIO). The median difference between calculated and measured alkalinity is $1 \%$ and the two generally agree within $\pm 6 \%(13 / 18)$, about twice the sum of each investigator's estimated uncertainties. 


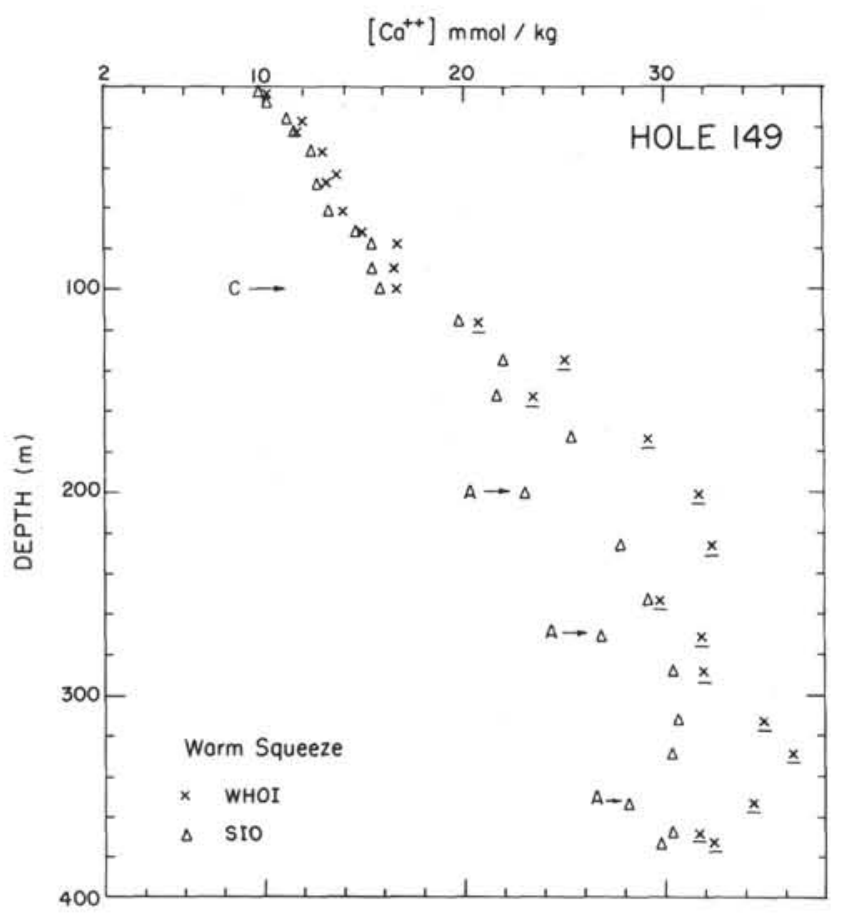

Figure 12. Site 149 calcium profile (warm squeeze). Underlined data are considered inaccurate; $C=$ contamination with dye during drilling; $A=$ calcium titration result considered too low since it is accompanied by a complementary magnesium anomaly.

The directly measured values are probably more reliable. Alkalinity titrations on stored samples (WHOI) scatter badly about the SIO and QC results.

At Site 147 and the upper 70 meters at Site 148, the CS and WS alkalinities lie within about $4 \%$ of each other, with no apparent systematic trends. Below this depth at Site 148 , however, and at Site 149 , some interesting temperature effects appear, as noted by Gieskes (this volume). In the lower portion at Site 148 , the WS alkalinity is about 0.2 $\mathrm{meq} / \mathrm{kg}$ greater than the CS alkalinity. At Site 149 the same phenomenon is observed down to about 240 meters, where a transition occurs and the WS alkalinity is about 0.1 $\mathrm{meq} / \mathrm{kg}$ greater than the CS alkalinity. The cause of these differences is not immediately obvious, but several mechanisms can be proposed.

Alkalinity of the aqueous phase is a conservative property and can be changed only by a transfer of ions between sediment and pore water. Increases with warming might occur by:

1) release of $\mathrm{H}_{3} \mathrm{SiO}_{4}{ }^{-}, \mathrm{PO}_{4} \equiv, \mathrm{B}(\mathrm{OH})_{4}{ }^{-}$, or $\mathrm{OH}^{-}$from adsorption sites on clay minerals;

2) adsorption of calcium by clay minerals, causing dissolution of $\mathrm{CaCO}_{3}$ in order for the solution to return to saturation;

3) release of $\mathrm{H}^{+}$by clay minerals followed by solution of carbonate minerals.

Decreases with warming may occur by:

1) release of $\mathrm{H}^{+}$by clay minerals and no $\mathrm{CaCO}_{3}$ solution;

2) precipitation of $\mathrm{CaCO}_{3}$.
These mechanisms can be distinguished by considering the effect of temperature on both alkalinity and $p \mathrm{H}$.

Examination of the effects of the increase in squeezing temperature on water composition reveals that $\Sigma \mathrm{P}$ shows little change (Gieskes, this volume), $\Sigma \mathrm{Si}$ generally increases by 0.05 to $0.10 \mathrm{mmol} / \mathrm{kg}$ (Gieskes, this volume), and $\Sigma \mathrm{B}$ may increase by about $30 \%$ or about $0.1 \mathrm{mmol} / \mathrm{kg}$ (Manheim et al., this volume). It is possible that $\left[\mathrm{H}_{3} \mathrm{SiO}_{4}{ }^{-}\right],\left[\mathrm{B}(\mathrm{OH})_{4}{ }^{-}\right]$, or more negatively charged species of these ions are adsorbed on clay minerals and released on warming, consequently increasing $\Sigma \mathrm{A}$. Manheim et al. (this volume) have noted a temperature effect for cations in the pore waters of these cores; divalent cations decrease and singly charged cations increase on warming. No temperature effect, however, is apparent for the major anions, chloride and sulfate. If $\left[\mathrm{B}(\mathrm{OH})_{4}{ }^{-}\right]$and $\left[\mathrm{H}_{3} \mathrm{SiO}_{4}{ }^{-}\right]$ should be released at the $p \mathrm{H}$ observed in these pore waters, they would react with $\left[\mathrm{H}^{+}\right]$and consequently increase the $p \mathrm{H}$.

There is a tendency for $\left[\mathrm{Ca}^{++}\right]$to be absorbed by clay minerals and decrease by a few percent as temperature is increased. If this effect is balanced by a release of $\mathrm{Na}^{+}$and $\mathrm{K}^{+}$, and $\mathrm{CaCO}_{3}$ dissolves until saturation equilibrium is regained, alkalinity increases must also be accompanied by $p \mathrm{H}$ increases.

Since clay minerals release the univalent cations $\mathrm{K}^{+}$and $\mathrm{Na}^{+}$, it seems likely that they may also release $\mathrm{H}^{+}$. The reaction

$$
\mathrm{CaCO}_{3}+\mathrm{H}^{+} \rightarrow \mathrm{Ca}^{++}+\mathrm{HCO}_{3}^{-}
$$

could then occur, increasing alkalinity. If the carbonate phase interacts with the aqueous phase in this manner, an alkalinity increase on warming must be accompanied by a $p \mathrm{H}$ decrease sufficiently large to drive this reaction to the right, despite the decrease in calcite solubility.

If clay minerals release $\left[\mathrm{H}^{+}\right]$and the carbonate phase is inert, alkalinity should decrease and $p \mathrm{H}$ should also decrease. If clay minerals do not affect the alkalinity but the carbonate phase is reactive, precipitation of $\mathrm{CaCO}_{3}$ should occur, and again both alkalinity and $p \mathrm{H}$ should decrease. Thus, the alkalinity and $p \mathrm{H}$ can be used together to determine the nature of the influence of the clay phase and the responsiveness of the carbonate phase.

In $30 / 45$ samples, alkalinity increases with temperature. As pointed out earlier, these appear to be real variations, showing depth dependence and increases often several times larger than the estimated analytical error. These increases are usually $(21 / 30)$ accompanied by a $\mathrm{pH}$ decrease (to be discussed more completely in the following section) and only a few (4/30) show a $p \mathrm{H}$ increase. This strongly supports the hypothesis that, with an increase in temperature, clay minerals release $\left[\mathrm{H}^{+}\right]$ions (or possibly absorb $\left[\mathrm{OH}^{-}\right]$, and $\mathrm{H}_{2} \mathrm{O} \rightarrow\left[\mathrm{OH}^{-}\right]+\left[\mathrm{H}^{+}\right]$) causing carbonate to dissolve and alkalinity to increase. Thus, both clay and carbonate phases are capable of responding rapidly to temperature and chemical changes in their environment.

At Site 149, a change in lithology from calcareous clay to calcareous radiolarian ooze occurs between 195 and 240 meters. This transition is reflected in the temperature effect on alkalinity. As the amount of clay drastically decreases, 
TABLE 2a

Apparent Constants for Seawater

$$
\begin{aligned}
& \text { (1) } p K_{1}^{L}=6.339-7.78 \times 10^{-3} \times \mathrm{T}+7.1 \times 10^{-5} \mathrm{~T}^{2}-0.01 \times \mathrm{C} 1 \\
& \text { (2) } p K_{2}^{L}=9.775-1.09 \times 10^{-2} \times \mathrm{T}-3.57 \times 10^{-5} \times \mathrm{T}^{2}-0.02 \times \mathrm{C} 1 \\
& \text { (3) } p K_{B}^{L}=9.255-1.06 \times 10^{-2} \times \mathrm{T}+3.57 \times 10^{-5} \times \mathrm{T}^{2}-0.016 \times \mathrm{C} 1 \\
& \text { (4) } K_{s p}^{\mathrm{C}}=\left(0.69-6.3 \times 10^{-3} \times \mathrm{T}\right) \times 10^{-6} \times \mathrm{C} 1 / 19.0 \\
& K_{i}(\mathrm{P}) / K_{i}(1 \mathrm{bar})=\operatorname{Exp}\left[-\Delta \mathrm{V}_{\mathrm{i}} \times(\mathrm{P}-1) / \mathrm{R}(\mathrm{T}+2731)\right] \\
& { }_{\alpha}=770 .-29.5 \times \mathrm{T}+0.685 \times \mathrm{T}^{2}-7.5 \times 10^{-3} \times \mathrm{T}^{3} \\
& \alpha=\alpha_{\mathrm{O}} \times 10^{-7} /\left(1.013 \times \text { Exp }\left[2.303 \times\left(0.0806-7.4 \times 10^{-4} \times \mathrm{T}\right) \times \mathrm{C} 1 / 20\right]\right) \\
& \operatorname{mol} / 1-\mathrm{mbars}
\end{aligned}
$$

$$
\begin{aligned}
& \mathrm{T}=\text { temperature }\left({ }^{\circ} \mathrm{C}\right) \\
& \mathrm{Cl}=\text { chlorinity }(\%) \\
& \mathrm{P}=\text { pressure }(\text { bars }) \\
& \Delta \mathrm{V}_{1}=-19.0 \mathrm{cc} / \mathrm{mole} \\
& \Delta \mathrm{V}_{2}=-10.7 \mathrm{cc} / \mathrm{mole} \\
& \Delta \mathrm{V}_{3}=-23.1 \mathrm{cc} / \mathrm{mole} \\
& \Delta \mathrm{V}_{4}=-29.7 \mathrm{cc} / \mathrm{mole} \\
& \mathrm{R}=83.14 \mathrm{cc} \text {-bars } / \text { mol-degree }
\end{aligned}
$$

the alkalinity response to warming changes from an increase to a decrease of about $0.05 \mathrm{meq} / \mathrm{kg}$, suggesting that precipitation of carbonate occurs. Since $p \mathrm{H}$ does not always show a corresponding decrease, some of the carbonate precipitation may be countered by the solution of anions of acids which are weaker than carbonic acid.

To estimate the magnitude of each of these processes, the $p \mathrm{H}$ (Table 5) and alkalinity (Table 1 ) data for each sample were used to calculate $\Sigma \mathrm{CO}_{2}$. The difference in $\Sigma \mathrm{CO}_{2}$ between CS and WS samples is attributed to solution or precipitation of $\mathrm{CaCO}_{3}$. The amount of strong acid or weak base required to account for the alkalinity change which cannot be attributed to carbonate solution or precipitation was then calculated. The resulting trends are listed in Table 6 . In all but two regions, release of $\left[\mathrm{H}^{+}\right]$by clay minerals and solution of carbonate is the dominant effect. In these two regions, carbonate precipitation and solution of anions of weak acids is apparent. At Site 149, this correlates with the disappearance of clay minerals, but at Site 148, the reason is unexplained.

\section{$p \mathrm{H}$}

Three sets of shipboard $p \mathrm{H}$ measurements were made on each sample, two by Gieskes on the water samples extruded at $4^{\circ} \mathrm{C}$ (CS) and $22^{\circ} \mathrm{C}$ (WS) and one by Broecker by inserting electrodes directly into the sediment (PI). A glass capillary electrode in series with surface seawater and a saturated calomel electrode was used for the first two sets of measurements, and an ORION R model 90-02 double junction reference electrode and a Beckman 40471 glass electrode were used for the third set. Standardization was

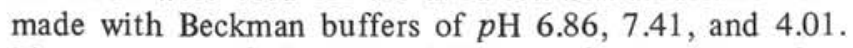
The accuracy of the CS and WS samples is estimated at $\pm 0.05 p \mathrm{H}$ units and that of the PI samples at $\pm 0.08 p \mathrm{H}$ units. The measurement temperature was usually 26 to $30^{\circ} \mathrm{C}$ for the pore water measurements and 18 to $25^{\circ} \mathrm{C}$ for the punch-in measurements. This data is tabulated in Table 5 .

To make all sets of measurements comparable, the alkalinity and $p \mathrm{H}$ at the measurement temperature were used to calculate $\Sigma \mathrm{CO}_{2}$, and, making the assumption that $\Sigma \mathrm{CO}_{2}$ and alkalinity are independent of temperature, these two quantities were then used to calculate the $p \mathrm{H}$ at $25^{\circ} \mathrm{C}$. The results of this calculation are also listed in Table 5 and are plotted in Figures 16 to 18 . The magnitude of $p \mathrm{H}$ temperature dependence can be estimated from Figure 19 in which $p \mathrm{H}$ is plotted as a function of temperature for pore waters with $p \mathrm{H}$ 's of 7.0 and 8.0 at $25^{\circ} \mathrm{C}$. This calculation was made for waters ranging in composition from seawater to varieties having the compositional extremes listed in Table $2 b$ The resulting plots are indistinguishable in Figure 19. Thus, $p \mathrm{H}$ variation with temperature is primarily a function of $p \mathrm{H}$ and the temperature dependence of $K_{1}^{\prime}, K_{2}^{\prime}$, taken here to be that measured by Lyman (1957). Solution and precipitation of calcite would change the slope of this curve slightly, but not introduce a serious error in the temperature correction.

When all three sets of measurements are recalculated to $25^{\circ} \mathrm{C}$, removing the temperature effect, it is clear from Table 5 that systematic differences exist. In most regions PI $<$ WS $<$ CS. The median differences between PI and WS measurements, and between WS and CS measurements, are summarized in Table 7. The differences appear to be real. Individual measurements usually fall within $0.08 \mathrm{pH}$ units of the median differences (46/58 for CS-WS, 29/41 for WS-PI). As suggested earlier in this paper, the discrepancy 
TABLE 2b

Adjustment of Constants from Seawater to Pore Water for Water of $19 \%$ at $25^{\circ} \mathrm{C}$

\begin{tabular}{lcccc}
\hline \multicolumn{1}{c}{ Pore water with: } & $K_{1}^{\prime} / K_{1}^{L}$ & $K_{2}^{\prime} / K_{2}^{L}$ & $K_{\mathrm{B}}^{\prime} / K_{\mathrm{B}}^{L}$ & $K_{s p}^{\prime} / K_{s p}^{C}$ \\
\hline Seawater composition & 1.000 & 1.000 & 1.000 & 1.000 \\
Seawater comp., no $\left[\mathrm{SO}_{4}{ }^{=}\right]{ }^{++}$ & 1.026 & 1.066 & 1.026 & 1.005 \\
Seawater comp., $0.5 \times\left[\mathrm{Mg}^{++}\right]_{S W}$ & 0.913 & 0.722 & 0.913 & 0.667 \\
Seawater comp., $0.5 \times\left[\mathrm{Ca}^{++}\right]_{S W}$ & 0.983 & 0.982 & 0.983 & 0.967 \\
Seawater comp., $2 \times\left[\mathrm{Ca}^{++}\right]_{S W}$ & 1.034 & 1.034 & 1.034 & 1.066 \\
Seawater comp., $10 \times\left[\mathrm{HCO}_{3}{ }^{-}\right]_{S W}$ & 0.988 & 0.967 & 0.988 & 1.017 \\
\hline
\end{tabular}

between CS and WS waters may be due to release of $\mathrm{H}^{+}$ ions from clay minerals as the squeezing temperature is increased. Again, this effect disappears as the clay fraction decreases in the lower region at Site 149.

The differences between PI and WS $p \mathrm{H}$ are more difficult to explain, since the PI measurement temperature is close to $22^{\circ} \mathrm{C}$, the warm squeezing temperature. One possibility is that calcite may dissolve in extruded water samples due to the pressure increase. The terminal squeezing pressure was typically about $4500 \mathrm{~kg}$ total load, or about $70 \mathrm{~atm}$. If half this value is chosen to represent the average WS equilibration pressure between water and calcite, calculation of the $\Sigma \mathrm{CO}_{2}$ and alkalinity increases expected from the pressure increase suggests that the WS $p \mathrm{H}$ should be 0.02 units greater than $\mathrm{PI} p \mathrm{H}$. Thus, only a small portion of the difference can be attributed to squeezing pressure.

At Site 147, the large difference may be attributed to $\mathrm{CO}_{2}$ loss during squeezing from the gassy core, after the PI measurement was made. $p_{\mathrm{CO}_{2}}$ of these samples was about $0.1 \mathrm{~atm}$ (Hammond et al., LDGO, this volume) and even a brief exposure of the samples to the atmosphere could have had a marked effect on $p \mathrm{H}$. At Site 148, the two measurements are closer but still significantly different. Gieskes (personal communication) has suggested that a difference of $0.1 p \mathrm{H}$ units may be due to the difference in the liquid junction potential of the electrodes at the PI measurement temperature of $19^{\circ} \mathrm{C}$ and the WS measurement temperature of $27^{\circ} \mathrm{C}$. This could also account for the discrepancy in the upper region at Site 149 but would increase the difference in the middle region. To summarize, $\mathrm{PI} p \mathrm{H}$ is consistent with $\mathrm{WS} p \mathrm{H}$ within about 0.2 units. The estimated measurement errors could account for half of this, but a systematic difference of about 0.1 units remains unexplained. This might be an artifact of liquid junction potentials, or perhaps a $\mathrm{CO}_{2}$ loss between the two sets of measurements.

One aim of the geochemistry leg was to establish a reliability for the $p \mathrm{H}$ measurements. Except at Site 147, all three sets of measurements are consistent to 0.2 units. Two other estimates of $p \mathrm{H}$ can be made, one from $\Sigma \mathrm{CO}_{2}$ and $p \mathrm{CO}_{2}$ determinations (QC, Table 4) made on some $\mathrm{CS}$ samples, and another from $p \mathrm{CO}_{2}$ measurements on gas pockets at Site 147. The $p \mathrm{H}$ values calculated (Table 5) from the first are about $0.5 p \mathrm{H}$ units greater than those measured at Site 147 (Figure 16) and about $0.25 \mathrm{pH}$ units greater than those measured at Site 148 (Figure 17). This discrepancy has been attributed earlier in this paper to a $\mathrm{CO}_{2}$ loss from QC samples of about $6 \%$, but does not rule out the argument that all the $p \mathrm{H}$ measurements could be grossly in error, and, consequently, the calculation of $\Sigma \mathrm{CO}_{2}$ from alkalinity and $p \mathrm{H}$ is in error. The latter explanation is unlikely because the second estimate (Table 5 , Figure 16) of $p \mathrm{H}$, made from alkalinity (SIO) and the $p \mathrm{CO}_{2}$ of the gas pockets from Site 147 (LDGO), is consistent with PI results. Although some scatter exists, they show no systematic variation from the PI $p \mathrm{H}$ and also show similar systematic differences when compared to WS values, supporting the $\mathrm{CO}_{2}$ loss hypothesis. Another argument for accepting the $p \mathrm{H}$ measurements as more reliable than those calculated from $\Sigma \mathrm{CO}_{2}$ and $p \mathrm{CO}_{2}$ is that the former indicate a degree of $\mathrm{CaCO}_{3}$ saturation at squeezing conditions which is generally between 0.6 and 2.4 , while the QC data yields far greater values. This will be discussed in the following section. Thus, the WS and CS measurements appear to be consistent within the estimated error of 0.05 units in each, if the influences of clay minerals are taken into account. PI measurements are consistent with gas pocket $p \mathrm{CO}_{2}$ within 0.2 units, although they show systematic differences from WS and CS measurements, some of which might be due to liquid junction potentials. Undoubtedly, some of the scatter with depth among the three sets of data is due to analytical error, but it is likely that part of this may be real, since two or three types of measurements often show similar anomalies at the same level.

\section{DEGREE OF SATURATION OF $\mathrm{CaCO}_{3}$}

Calcite is present at all levels in each drill hole. Perhaps, as suggested by Gieskes (this volume), the most instructive test of the consistency of the analytical data and the model for apparent constant estimation (MACE) is to calculate the degree of saturation of calcite,

$$
\Omega=\left[\mathrm{Ca}^{++}\right]\left[\mathrm{CO}_{3}{ }^{=}\right] / K_{s p}^{\prime}
$$

for each sample at the sampling conditions. Unfortunately, the picture is clouded by several problems. It has been shown earlier in this paper that carbonate solution and precipitation can occur on short time scales. It has not been shown, however, that the kinetics of these reactions are sufficiently rapid for equilibrium to be attained, or, more 
TABLE 3a

Dissociated Fraction of Weak Acids in Seawater of $19.4 \%$ Chlorinity at $25^{\circ} \mathrm{C}$

\begin{tabular}{lll}
\hline & $p \mathrm{H}=7.0$ & $p \mathrm{H}=8.0$ \\
$\mathrm{H}_{3} \mathrm{SiO}_{4}{ }^{-} / \Sigma \mathrm{Si}$ & 0.004 & 0.040 \\
$\mathrm{H}_{2} \mathrm{PO}_{4}{ }^{-} / \Sigma \mathrm{P}$ & 0.101 & 0.009 \\
$\mathrm{HPO}_{4} \equiv / \Sigma \mathrm{P}$ & 0.876 & 0.787 \\
$\mathrm{PO}_{4}{ }^{=} / \Sigma \mathrm{P}$ & 0.023 & 0.205 \\
$\mathrm{~B}\left(\mathrm{OH}_{4}{ }^{-} / \Sigma \mathrm{B}\right.$ & 0.020 & 0.163 \\
$\mathrm{HCO}_{3}{ }^{-} / \Sigma \mathrm{CO}_{2}$ & 0.902 & 0.917 \\
$\mathrm{CO}_{3}{ }^{-} / \Sigma \mathrm{CO}_{2}$ & 0.008 & 0.072 \\
\hline
\end{tabular}

TABLE 3b

Dissociation Constants for Seawater of $19.4 \%$ Chlorinity at $25^{\circ} \mathrm{C}, \mathrm{HA}^{-x} \leftrightharpoons \mathrm{H}^{+}+\mathrm{A}^{-x-1}$

\begin{tabular}{ccl}
\hline \multicolumn{1}{c}{ Acid } & $p K^{\text {acid }}$ & \multicolumn{1}{c}{ Source } \\
\hline $\mathrm{H}_{4} \mathrm{SiO}_{4}$ & 9.4 & Sillen, 1966 \\
$\mathrm{H}_{3} \mathrm{PO}_{4}$ & 1.61 & Kester and Pytkowicz, 1967 \\
$\mathrm{H}_{2} \mathrm{PO}_{4}{ }^{-}$ & 6.06 & Kester and Pytkowicz, 1967 \\
$\mathrm{HPO}_{4}{ }^{-}$ & 8.56 & Kester and Pytkowicz, 1967 \\
$\mathrm{H}_{3} \mathrm{BO}_{3} \cdot \mathrm{H}_{2} \mathrm{O}$ & 8.71 & Lyman, 1957 \\
$\mathrm{H}_{2} \mathrm{CO}_{3}$ & 6.00 & Lyman, 1957 \\
$\mathrm{HCO}_{3}^{-}$ & 9.10 & Lyman, 1957 \\
\hline
\end{tabular}

importantly, whether or not the reactive phase is calcite. Dolomite rhombs appear at Sites 147 and 148 (lithologic descriptions, this volume). If the pore water was saturated with calcite under in situ conditions, carbonate precipitation should have occurred as the cores were raised from the depths. As has been pointed out by Weyl (1957) and others, precipitation on a calcite substrate is likely to result in the construction of a magnesium-rich coating which inhibits further equilibration of solid and aqueous phases.

With these problems in mind, the sensitivity of the calculation to input parameters can be examined.

$$
\Omega=\frac{\left[\mathrm{Ca}^{++}\right]\left[\mathrm{CO}_{3}{ }^{-}\right]}{K_{s p}^{\prime}}=\frac{\left[\mathrm{Ca}^{++}\right]\left[\mathrm{HCO}_{3}{ }^{-}\right] K_{2}^{\prime}}{a_{\mathrm{H}^{+}} K_{s p}^{\prime}}
$$

and

$$
\underset{\Omega}{\Delta \Omega}=\frac{\Delta\left[\mathrm{Ca}^{++}\right]}{\left[\mathrm{Ca}^{++}\right]}+\frac{\Delta\left[\mathrm{HCO}_{3}{ }^{-}\right]}{\left[\mathrm{HCO}_{3}{ }^{-}\right]}-\frac{\Delta a_{\mathrm{H}^{+}}}{a_{\mathrm{H}^{+}}}+\frac{\Delta\left(K_{2}^{\prime} / K_{s p}^{\prime}\right)}{K_{2}^{\prime} / K_{s p}^{\prime}}
$$

The ratio $K_{2}^{\prime} / K_{s p}^{\prime}$ will increase up to $10 \%$ with depth as the fraction of free $\left[\mathrm{HCO}_{3}{ }^{-}\right]$increases, primarily due to the decrease in $\left[\mathrm{Mg}^{++}\right]$. Assuming this ratio is correct for seawater, taking $10 \%$ as an upper limit for any error MACE might introduce into the calculation or $\Omega$, and taking $\left[\mathrm{HCO}_{3}{ }^{-}\right] \approx \Sigma$ alkalinity, the error in $\Omega$ can be estimated at about $\pm 30 \%$ (Table 8 ). If MACE overestimates the effects of $\left[\mathrm{Mg}^{++}\right]$decrease, it will be difficult to detect, but an underestimate greater than a factor of 2 could introduce a significant systematic trend in $\Omega$ with depth.

$\Omega$ was calculated for CS and WS samples, using the pore water composition listed in Table 1 , the $p \mathrm{H}$ in Table 5 , the squeezing temperature, and estimated average squeezing pressure of $35 \mathrm{~atm}$ for Sites 147 and 148 and $23 \mathrm{~atm}$ for Site 149 (L. Waterman, personal communication). Calculations of $\Omega$ for PI measurements were made at 1 bar and the measurement temperature, using water composition interpolated from CS and WS analyses. The results of these calculations are plotted in Figures 20 to $22 . \Omega$ is approximately constant with depth for each sample type in each site, but CS results are systematically more undersaturated than WS and PI values, and each site appears to have a distinct $\Omega$ (Table 9).

Figure 23 schematically illustrates the pressure and temperature history of each sample. Dashed lines indicate changes which should cause calcite precipitation, solid lines those which should cause solution. To quantitatively estimate the magnitude of these changes, a pressure reduction of $50 \mathrm{~atm}$ should cause the precipitation of 0.1 mmol $\mathrm{CaCO}_{3} / 1$ and warming from $4^{\circ} \mathrm{C}$ to $22^{\circ} \mathrm{C}$ should cause an equal amount of solution. If precipitation kinetics are too slow to allow equilibrium to be attained, PI samples should be supersaturated, with those from Site 149 being farthest from equilibrium. The results, despite their scatter, indicate that PI measurements are consistent with the hypothesis that pore water equilibrates rapidly with calcite.

Cs and WS samples do not suggest this as clearly. Several puzzling trends exist. $\Omega$ for CS samples tends to be smaller than $\Omega$ for WS samples, and at Site 149, CS samples appear undersaturated with calcite. Since calcite appeared to be dissolving as temperature was increased, $\Omega$ for WS samples should be close to or less than 1.0. The third problem is that the core expected to be farthest from equilibrium when sampled, Site 149, has pore waters closest to saturation. As suggested earlier in this paper, $\mathrm{CO}_{2}$ loss from Site 147 pore water samples during squeezing may have increased the $p \mathrm{H}$, and consequently $\Omega$. Since $p_{\mathrm{CO}_{2}}$ increases with temperature, greater gas loss would be expected from WS samples, explaining the higher WS $\Omega$. The same argument could be applied to Site 148, where the $p_{\mathrm{CO}_{2}}$ is roughly $0.01 \mathrm{~atm}$. Only a small amount of $\mathrm{CO}_{2}$ loss $(1-2 \%)$ would be required to change the $p \mathrm{H}$ by 0.15 units and bring $\Omega$ close to 1.0 . At Site 149 the $p_{\mathrm{CO}_{2}}$ of samples is roughly half that of Site 148 samples and consequently less $\mathrm{CO}_{2}$ loss might be expected. WS $\Omega$ is close to 1.0 as expected.

To summarize, it appears that pore water may equilibrate rapidly with calcite since Leg $15 p \mathrm{H}$ measurements are consistent with this hypothesis. Squeezed samples from Sites 147 and 148 show slight calcite supersaturation and may have lost $\mathrm{CO}_{2}$ during collection. The undersaturation exhibited by CS samples from Site 149 remains a mystery.

It is interesting to note that $\Omega$ is constant to better than $20 \%$ in each set of measurements and shows no systematic 
TABLE 4

Comparison of $\Sigma \mathrm{CO}_{2}+p_{\mathrm{CO}_{2}}$ and $\mathrm{Alk}+p \mathrm{H}$

\begin{tabular}{|c|c|c|c|c|c|c|c|c|}
\hline \multirow[b]{2}{*}{ Sample } & \multirow{2}{*}{$\begin{array}{l}\text { Depth } \\
\text { (m) }\end{array}$} & \multicolumn{3}{|c|}{$\Sigma \mathrm{CO}_{2}(\mathrm{mmol} / \mathrm{kg})$} & \multicolumn{3}{|c|}{ Salk meq/kg } & \multirow{2}{*}{$\frac{p_{\mathrm{CO}_{2}}\left(10^{-3} \mathrm{~atm}\right)}{\mathrm{QC}}$} \\
\hline & & QC & SIO & $\Delta(\%)$ & SIO & QC & $\Delta(\%)$ & \\
\hline $147 \mathrm{~B}-1-3$ & 4.25 & 15.02 & 18.32 & -21.9 & 17.72 & 15.80 & 10.8 & 5.97 \\
\hline $147 \mathrm{~B}-1-4$ & 4.75 & 13.44 & 17.46 & -29.9 & 17.60 & 14.47 & 17.6 & 3.75 \\
\hline $147 \mathrm{~B}-1-4$ & 5.10 & 14.63 & 15.11 & -3.3 & 15.17 & 15.00 & 1.1 & 8.42 \\
\hline $147 \mathrm{~B}-2-2$ & 15.0 & 8.18 & 8.39 & -2.5 & 8.18 & 8.74 & -6.8 & 2.66 \\
\hline $147 \mathrm{~B}-2-6$ & 21 & 12.51 & 15.05 & -12.3 & 13.75 & 13.80 & -0.4 & 2.40 \\
\hline $147 \mathrm{~B}-6-2$ & 51 & 9.50 & 10.09 & -6.1 & 10.06 & 10.22 & 1.6 & 2.23 \\
\hline $148-1-4$ & 6 & 3.60 & 3.96 & -9.9 & 4.00 & 3.84 & 4.0 & 1.39 \\
\hline $148-2-1$ & 11 & 2.91 & 3.51 & -20.9 & 3.51 & 2.99 & 14.9 & 2.05 \\
\hline $148-3-3$ & 22 & 5.21 & 5.24 & -0.4 & 5.23 & 5.41 & -3.4 & 2.75 \\
\hline $148-4-3$ & 31 & 4.80 & 5.04 & -4.9 & 5.02 & 4.99 & 0.6 & 2.48 \\
\hline $148-7-3$ & 59 & 7.60 & 7.70 & -1.3 & 7.61 & 7.92 & -4.1 & 3.20 \\
\hline $148-7-3$ & 59 & 7.49 & 7.70 & -1.9 & 7.61 & 7.63 & -0.2 & 5.45 \\
\hline $148-8-3$ & 67 & 7.71 & 7.70 & 0.0 & 7.66 & 7.86 & -2.6 & 4.72 \\
\hline $148-10-3$ & 86 & 6.54 & 6.63 & -1.3 & 6.72 & 6.76 & -0.6 & 3.28 \\
\hline $148-12-4$ & 106 & 4.71 & 5.12 & -8.6 & 5.27 & 4.87 & 7.5 & 2.42 \\
\hline $148-18-2$ & 159 & 2.86 & 3.68 & -28.5 & 3.73 & 2.86 & 23.3 & 2.78 \\
\hline $148-20-3$ & 179 & 3.24 & 3.67 & -13.2 & 3.63 & 3.25 & 10.5 & 2.94 \\
\hline $148-23-4$ & 209 & 2.88 & 3.08 & -7.0 & 3.05 & 2.86 & 6.0 & 3.03 \\
\hline Median & & & & $-6.5 \%$ & & & $+0.5 \%$ & \\
\hline
\end{tabular}

$\Delta=\left(\frac{\text { measured }- \text { calculated }}{\text { measured }}\right) \times 100$.

depth dependence. This suggests that the estimated errors are realistic with $p \mathrm{H}$ measurements introducing the major error in $\Omega$ and that MACE may be reliable to better than $10 \%$, even at Site 149 where the largest $\left[\mathrm{Ca}^{++}\right]$and $\left[\mathrm{Mg}^{++}\right]$changes are observed. It should be pointed out that an alternative explanation might be advanced to explain the $p H$ and $\Omega$ data. It has been suggested (most recently by Suess, 1970) that organic coatings can develop on calcite surfaces and inhibit rapid solution and precipitation. Sites 147 and 148 have significant organic content while Site 149 does not. Attributing the difference between PI and WS $p \mathrm{H}$ measurements to liquid junction potentials, claiming $\mathrm{CO}_{2}$ loss occurred at Site 147, and that at Site 149 calcite and water can equilibrate rapidly but are inhibited by organic shields on calcite crystals at Sites 147 and 148 leads to the conclusion that Sites 147 and 148 water exhibit saturation under in situ conditions and that little precipitation has occurred as cores were retrieved. This hypothesis still fails to explain the CS undersaturation at Site 149 and also the observed alkalinity increases in the lower portions at Site 148. Consequently, the $\mathrm{CO}_{2}$ loss hypothesis is favored although it is difficult to unequivocally ascertain.

\section{SUMMARY}

1. The major element data from Leg 15 have been examined and appear reliable with the exception of $\left[\mathrm{Ca}^{++}\right]$ measurements made by atomic absorption.

2. The Garrels and Thompson (1962) model predicts that the apparent constants for the carbonic acid system will be different in pore water than in seawater. Their model is used to develop a computational procedure which calculates apparent constants for pore waters by adjusting experimentally determined seawater constants. This procedure predicts that if seawater constants were used, they would introduce a systematic error of up to $10 \%$ in calculating $\Omega$, the degree of saturation of calcite, primarily due to the low $\left[\mathrm{Mg}^{++}\right]$in pore waters. It is estimated that the procedure is accurate to better than $10 \%$.

3. The several carbonate parameters measured, $\Sigma$ alkalinity, $\Sigma \mathrm{CO}_{2}, p_{\mathrm{CO}_{2}}$, and three sets of $p \mathrm{H}$, are internally consistent, although it appears that a $\mathrm{CO}_{2}$ loss of about $6 \%$ may have occurred during collection and storage of the $\mathrm{QC}$ samples. Measurements of alkalinity and $p \mathrm{H}$ can be used to show that pore water may equilibrate rapidly with calcite as temperature and pressure fluctuate, as might have been anticipated from the saturometer experiments of Weyl (1967) and Ben-Yaakov and Kaplan (1971). Consequently, to calculate carbonate parameters in situ, the temperature and pressure must be noted when pore water last contacts sediment. This equilibration may be hindered by organic material.

4. Clay minerals, where present, release $\mathrm{H}^{+}$ions as they are warmed. The reaction $\mathrm{CaCO}_{3}+\mathrm{H}^{+} \rightarrow \mathrm{Ca}^{++}+\mathrm{HCO}_{3}-$ occurs, increasing alkalinity and decreasing $\mathrm{pH}$. In regions where clay minerals are rare, $\mathrm{CaCO}_{3}$ precipitation occurs as sediment is warmed, causing a decrease in alkalinity. The expected accompanying decrease in $p \mathrm{H}$ is not clearly apparent.

\section{ACKNOWLEDGMENTS}

I am indebted to the members of the scientific and technical staff of the Glomar Challenger for their assistance in data collection and especially to Dr. W. S. Broecker who made the punch-in $p \mathrm{H}$ measurements, provided stimulating 
D. E. HAMMOND

TABLE 5

Comparison of Calculated Measured $p H$

\begin{tabular}{|c|c|c|c|c|c|c|c|c|c|c|c|c|}
\hline \multirow[b]{2}{*}{ Sample } & \multirow[b]{2}{*}{ Depth } & \multicolumn{2}{|c|}{$\begin{array}{c}\text { Cold } \\
\text { Squeeze } \\
\end{array}$} & \multicolumn{2}{|c|}{$\begin{array}{c}\text { Warm } \\
\text { Squeeze }\end{array}$} & \multicolumn{2}{|c|}{ Punch-In } & \multicolumn{5}{|c|}{$p \mathrm{H}\left(25^{\circ} \mathrm{C}\right)$} \\
\hline & & $p \mathrm{H}$ & $\mathrm{T}$ & $p \mathrm{H}$ & $\mathrm{T}$ & $p \mathrm{H}$ & $\mathbf{T}$ & $\mathrm{CS}$ & WS & PI & $\mathrm{QC}$ & LDGO \\
\hline \multicolumn{13}{|l|}{ Site 147} \\
\hline $\begin{array}{l}147 \mathrm{~B}-1-2 \\
147 \mathrm{~B}-1-3 \\
147 \mathrm{~B}-1-4 \\
147 \mathrm{~B}-1-4 \\
147 \mathrm{~B}-1-4\end{array}$ & $\begin{array}{l}2.5 \\
4.2 \\
4.7 \\
4.8 \\
5.1\end{array}$ & $\begin{array}{l}7.36 \\
7.28 \\
7.58 \\
7.62 \\
7.56\end{array}$ & $\begin{array}{l}27.6 \\
27.8 \\
28.0 \\
28.0 \\
28.0\end{array}$ & $\begin{array}{l}6.77 \\
6.20 \\
7.62 \\
7.57 \\
7.52\end{array}$ & $\begin{array}{l}27.6 \\
27.8 \\
27.7 \\
28.0 \\
28.0\end{array}$ & $\begin{array}{l}6.93 \\
7.01 \\
7.36 \\
7.16 \\
7.19\end{array}$ & $\begin{array}{l}22.0 \\
23.5 \\
24.0 \\
22.0 \\
24.8\end{array}$ & $\begin{array}{l}7.38 \\
7.30 \\
7.61 \\
7.65 \\
7.59\end{array}$ & $\begin{array}{l}6.78 \\
6.21 \\
7.64 \\
7.60 \\
7.54\end{array}$ & $\begin{array}{l}6.92 \\
7.00 \\
7.35 \\
7.14 \\
7.19\end{array}$ & $\begin{array}{l}7.85 \\
8.02 \\
\\
7.67\end{array}$ & \\
\hline $\begin{array}{l}147 \mathrm{~B}-2-3 / 4 \\
147 \mathrm{~B}-2-2 \\
147 \mathrm{~B}-2-6 \\
147 \mathrm{~B}-4-3 / 4 \\
147-6-4\end{array}$ & $\begin{array}{l}8.5 \\
15.0 \\
21.0 \\
28 \\
47\end{array}$ & $\begin{array}{l}7.49 \\
7.30 \\
7.37 \\
7.25\end{array}$ & $\begin{array}{l}27.3 \\
28.2 \\
26.4 \\
27.9\end{array}$ & $\begin{array}{l}7.29 \\
7.29\end{array}$ & $\begin{array}{l}28.2 \\
26.4\end{array}$ & $\begin{array}{l}7.05 \\
6.94\end{array}$ & $\begin{array}{l}25.0 \\
25.7\end{array}$ & $\begin{array}{l}7.51 \\
7.32 \\
7.38 \\
7.27\end{array}$ & $\begin{array}{l}7.31 \\
7.30\end{array}$ & $\begin{array}{l}7.05 \\
6.94\end{array}$ & $\begin{array}{l}7.96 \\
8.20\end{array}$ & 7.14 \\
\hline $\begin{array}{l}147 \mathrm{~B}-6-2 \\
147-8-2 / 3 \\
147 \mathrm{~B}-7-4 \\
147-10-3 \\
147-10-3 / 4\end{array}$ & $\begin{array}{l}51 \\
63 \\
63 \\
82 \\
82\end{array}$ & $\begin{array}{l}7.55 \\
7.21 \\
7.34\end{array}$ & $\begin{array}{l}27.9 \\
28.4 \\
28.4 \\
\\
26.7\end{array}$ & $\begin{array}{l}7.59 \\
7.35\end{array}$ & $\begin{array}{l}27.9 \\
28.4\end{array}$ & $\begin{array}{l}7.03 \\
6.76 \\
6.64\end{array}$ & $\begin{array}{l}27.0 \\
28.0 \\
27.0\end{array}$ & $\begin{array}{l}7.57 \\
7.23 \\
7.36 \\
\\
6.98\end{array}$ & $\begin{array}{l}7.61 \\
7.37\end{array}$ & $\begin{array}{l}7.04 \\
6.77 \\
6.65\end{array}$ & 8.15 & $\begin{array}{l}6.84 \\
6.81 \\
6.96\end{array}$ \\
\hline $\begin{array}{l}147 \mathrm{~B}-9-4 \\
147 \mathrm{~B}-11-3 \\
147-14-3 \\
147 \mathrm{C}-2-1 \\
147 \mathrm{C}-2-2\end{array}$ & $\begin{array}{r}83 \\
100 \\
119 \\
126 \\
128\end{array}$ & $\begin{array}{l}7.05 \\
7.17 \\
7.12\end{array}$ & $\begin{array}{l}29.4 \\
29.0 \\
27.9\end{array}$ & $\begin{array}{l}6.95 \\
7.05 \\
\\
6.94\end{array}$ & $\begin{array}{l}29.4 \\
29.0 \\
27.9\end{array}$ & $\begin{array}{l}6.71 \\
6.72\end{array}$ & $\begin{array}{l}26.0 \\
27.5\end{array}$ & $\begin{array}{l}7.07 \\
7.19 \\
7.13\end{array}$ & $\begin{array}{l}6.97 \\
7.07 \\
6.95\end{array}$ & $\begin{array}{l}6.71 \\
6.73\end{array}$ & & $\begin{array}{l}6.75 \\
6.61 \\
6.89 \\
6.85\end{array}$ \\
\hline $\begin{array}{l}147 C-4-4 \\
147 C-7-3 \\
147 C-7-4\end{array}$ & $\begin{array}{l}148 \\
175 \\
176\end{array}$ & $\begin{array}{l}7.11 \\
7.43\end{array}$ & $\begin{array}{l}27.2 \\
27.4\end{array}$ & $\begin{array}{l}6.98 \\
7.42\end{array}$ & $\begin{array}{l}27.2 \\
27.4\end{array}$ & & & $\begin{array}{l}7.12 \\
7.45\end{array}$ & $\begin{array}{l}6.99 \\
7.44\end{array}$ & & & $\begin{array}{l}6.77 \\
6.92\end{array}$ \\
\hline \multicolumn{13}{|l|}{ Site 148} \\
\hline $\begin{array}{l}148-1-2 \\
148-1-4 \\
148-2-1 \\
148-2-3 \\
148-3-3\end{array}$ & $\begin{array}{r}3 \\
6 \\
11 \\
13 \\
22\end{array}$ & $\begin{array}{l}7.64 \\
7.53 \\
7.46 \\
7.61 \\
7.48\end{array}$ & $\begin{array}{l}29.5 \\
29.0 \\
28.0 \\
28.6 \\
26.8\end{array}$ & $\begin{array}{l}7.54 \\
7.43 \\
7.92 \\
7.51 \\
7.44\end{array}$ & $\begin{array}{l}29.5 \\
28.5 \\
28.0 \\
28.6 \\
26.8\end{array}$ & $\begin{array}{l}7.34 \\
7.37 \\
7.89 \\
7.33 \\
7.42\end{array}$ & $\begin{array}{l}19.5 \\
20.0 \\
18.0 \\
22.0 \\
19.0\end{array}$ & $\begin{array}{l}7.68 \\
7.56 \\
7.48 \\
7.64 \\
7.49\end{array}$ & $\begin{array}{l}7.58 \\
7.46 \\
7.95 \\
7.54 \\
7.45\end{array}$ & $\begin{array}{l}7.30 \\
7.34 \\
7.82 \\
7.31 \\
7.38\end{array}$ & $\begin{array}{l}7.95 \\
7.65 \\
\\
7.76\end{array}$ & \\
\hline $\begin{array}{l}148-4-3 \\
148-5-2 \\
148-6-4 \\
148-7-3\end{array}$ & $\begin{array}{l}31 \\
39 \\
51 \\
59\end{array}$ & $\begin{array}{l}7.45 \\
7.46 \\
7.48 \\
7.41\end{array}$ & $\begin{array}{l}28.1 \\
28.5 \\
29.3 \\
29.4\end{array}$ & $\begin{array}{l}7.42 \\
7.42 \\
7.44 \\
7.49\end{array}$ & $\begin{array}{l}28.1 \\
28.5 \\
29.3 \\
29.4\end{array}$ & $\begin{array}{l}7.43 \\
7.42 \\
7.37 \\
7.43\end{array}$ & $\begin{array}{l}19.0 \\
18.0 \\
19.0 \\
15.5\end{array}$ & $\begin{array}{l}7.47 \\
7.49 \\
7.51 \\
7.44\end{array}$ & $\begin{array}{l}7.44 \\
7.45 \\
7.47 \\
7.53\end{array}$ & $\begin{array}{l}7.39 \\
7.37 \\
7.33 \\
7.36\end{array}$ & $\begin{array}{l}7.85 \\
7.56 \\
7.65\end{array}$ & \\
\hline $\begin{array}{l}148-8-3 \\
148-9-4 \\
148-10-3 \\
148-12-4 \\
148-14-3 \\
148-16-3\end{array}$ & $\begin{array}{r}67 \\
79 \\
86 \\
106 \\
122 \\
141\end{array}$ & $\begin{array}{l}7.46 \\
7.65 \\
7.61 \\
7.72 \\
7.50 \\
7.43\end{array}$ & $\begin{array}{l}29.0 \\
28.9 \\
28.0 \\
27.8 \\
28.6 \\
28.2\end{array}$ & $\begin{array}{l}7.41 \\
7.60 \\
7.71 \\
7.53 \\
7.42 \\
7.30\end{array}$ & $\begin{array}{l}29.0 \\
28.9 \\
28.0 \\
27.8 \\
28.6 \\
28.2\end{array}$ & $\begin{array}{l}7.41 \\
7.47 \\
7.52 \\
7.36 \\
7.51 \\
7.33\end{array}$ & $\begin{array}{l}17.5 \\
17.0 \\
19.0 \\
20.0 \\
20.0 \\
21.5\end{array}$ & $\begin{array}{l}7.49 \\
7.69 \\
7.64 \\
7.75 \\
7.53 \\
7.45\end{array}$ & $\begin{array}{l}7.44 \\
7.63 \\
7.74 \\
7.56 \\
7.45 \\
7.32\end{array}$ & $\begin{array}{l}7.36 \\
7.41 \\
7.47 \\
7.32 \\
7.47 \\
7.31\end{array}$ & $\begin{array}{l}7.78 \\
7.80\end{array}$ & \\
\hline $\begin{array}{l}148-18-2 \\
148-20-3 \\
148-23-4 \\
148-26-2\end{array}$ & $\begin{array}{l}159 \\
179 \\
209 \\
232\end{array}$ & $\begin{array}{l}7.61 \\
7.421 \\
7.40 \\
7.49\end{array}$ & $\begin{array}{l}27.4 \\
28.0 \\
30.0 \\
30.1\end{array}$ & $\begin{array}{l}7.51 \\
7.42 \\
7.73 \\
7.42\end{array}$ & $\begin{array}{l}27.4 \\
28.0 \\
30.0 \\
30.1\end{array}$ & 7.38 & 22.0 & $\begin{array}{l}7.63 \\
7.44 \\
7.44 \\
7.53\end{array}$ & $\begin{array}{l}7.53 \\
7.44 \\
7.78 \\
7.46\end{array}$ & 7.36 & $\begin{array}{l}7.47 \\
7.50 \\
7.42\end{array}$ & \\
\hline \multicolumn{13}{|l|}{ Site 149} \\
\hline $\begin{array}{l}149-2-2 \\
149-2-5 \\
149-3-5 \\
149-4-3 \\
149-5-3\end{array}$ & $\begin{array}{r}4 \\
8 \\
17 \\
23 \\
32\end{array}$ & $\begin{array}{l}7.51 \\
7.49 \\
7.28 \\
7.35 \\
7.46\end{array}$ & $\begin{array}{l}30.0 \\
30.0 \\
29.0 \\
28.4 \\
26.9\end{array}$ & $\begin{array}{l}7.47 \\
7.46 \\
7.37 \\
7.35 \\
7.44\end{array}$ & $\begin{array}{l}30.0 \\
30.0 \\
29.0 \\
28.4 \\
26.9\end{array}$ & $\begin{array}{l}7.44 \\
7.40 \\
7.30 \\
7.32 \\
7.35 \\
\end{array}$ & $\begin{array}{l}20.0 \\
20.0 \\
20.0 \\
20.0 \\
20.0\end{array}$ & $\begin{array}{l}7.55 \\
7.53 \\
7.31 \\
7.37 \\
7.47\end{array}$ & $\begin{array}{l}7.51 \\
7.51 \\
7.40 \\
7.37 \\
7.45\end{array}$ & $\begin{array}{l}7.40 \\
7.36 \\
7.27 \\
7.19 \\
7.30\end{array}$ & & \\
\hline $\begin{array}{l}149-6-4 \\
149-7-2 \\
149-8-4 \\
149-9-5 \\
149-10-2\end{array}$ & $\begin{array}{l}43 \\
49 \\
62 \\
72 \\
78\end{array}$ & $\begin{array}{l}7.38 \\
7.32 \\
7.32 \\
7.24\end{array}$ & $\begin{array}{l}27.0 \\
25.8 \\
26.0 \\
26.8\end{array}$ & $\begin{array}{l}7.30 \\
7.27 \\
7.32 \\
7.24\end{array}$ & $\begin{array}{l}27.0 \\
25.8 \\
26.0 \\
26.8\end{array}$ & $\begin{array}{l}7.33 \\
7.36 \\
7.29 \\
7.33 \\
7.38\end{array}$ & $\begin{array}{l}20.0 \\
20.0 \\
20.0 \\
20.0 \\
20.0\end{array}$ & $\begin{array}{l}7.39 \\
7.33 \\
7.33 \\
7.25\end{array}$ & $\begin{array}{l}7.31 \\
7.28 \\
7.33 \\
7.25\end{array}$ & $\begin{array}{l}7.30 \\
7.33 \\
7.26 \\
7.30 \\
7.34\end{array}$ & & \\
\hline
\end{tabular}


TABLE 5 - Continued

\begin{tabular}{|c|c|c|c|c|c|c|c|c|c|c|c|c|}
\hline \multirow[b]{2}{*}{ Sample } & \multirow[b]{2}{*}{ Depth } & \multicolumn{2}{|c|}{$\begin{array}{c}\text { Cold } \\
\text { Squeeze }\end{array}$} & \multicolumn{2}{|c|}{$\begin{array}{c}\text { Warm } \\
\text { Squeeze }\end{array}$} & \multicolumn{2}{|c|}{ Punch-In } & \multicolumn{5}{|c|}{$p \mathrm{H}(25 \mathrm{C})$} \\
\hline & & $p \mathrm{H}$ & $\mathrm{T}$ & $p \mathrm{H}$ & $\mathrm{T}$ & $p \mathrm{H}$ & $\mathrm{T}$ & $\mathrm{CS}$ & WS & PI & $\mathrm{QC}$ & LDGO \\
\hline $149-11-4$ & 90 & 7.23 & 29.0 & 7.23 & 29.0 & 7.38 & 20.0 & 7.26 & 7.25 & 7.34 & & \\
\hline $149-12-5$ & 100 & 7.12 & 29.0 & 7.21 & 29.0 & 7.40 & 20.0 & 7.14 & 7.23 & 7.37 & & \\
\hline $149-14-3$ & 116 & 7.21 & 29.0 & 7.14 & 29.0 & 7.40 & 20.0 & 7.23 & 7.16 & 7.37 & & \\
\hline $149-16-4$ & 135 & 7.06 & 29.0 & 6.95 & 29.0 & 7.01 & 20.0 & 7.08 & 6.97 & 6.98 & & \\
\hline $149-18-3$ & 153 & 7.13 & 29.0 & 7.12 & 29.0 & & & 7.15 & 7.14 & & & \\
\hline $149-20-4$ & 173 & 7.03 & 29.0 & 7.03 & 29.0 & 7.05 & 20.0 & 7.05 & 7.05 & 7.02 & & \\
\hline $149-23-4$ & 201 & 6.88 & 29.2 & 6.91 & 29.2 & & & 6.90 & 6.93 & & & \\
\hline $149-26-2$ & 226 & 6.98 & 28.5 & 6.92 & 28.5 & & & 7.00 & 6.94 & & & \\
\hline $149-29-3$ & 254 & 6.98 & 28.4 & 6.94 & 28.4 & & & 7.00 & 6.96 & & & \\
\hline $149-31-1$ & 271 & 6.97 & 28.0 & 7.00 & 28.0 & & & 6.98 & 7.01 & & & \\
\hline $149-33-1$ & 289 & 6.98 & 28.0 & 6.94 & 28.0 & & & 6.99 & 6.95 & & & \\
\hline $149-35-4$ & 313 & 6.96 & 28.0 & 6.98 & 28.0 & & & 6.97 & 6.99 & & & \\
\hline $149-37-3$ & 329 & 6.98 & 29.0 & 7.01 & 29.0 & & & 7.00 & 7.03 & & & \\
\hline $149-40-1$ & 354 & 7.01 & 29.0 & 7.01 & 29.0 & & & 7.03 & 7.03 & & & \\
\hline $149-41-5$ & 369 & 7.00 & 29.2 & 7.05 & 29.2 & & & 7.02 & 7.07 & & & \\
\hline $149-42-2$ & 374 & 7.00 & 28.0 & 7.07 & 28.0 & & & 7.01 & 7.09 & & & \\
\hline
\end{tabular}

discussion throughout the study, and with Mr. S. Emerson, reviewed the final manuscript. Drs. Gieskes, Presley, and Sayles are thanked for fruitful discussion and the use of their data prior to publication. Drs. Takahashi and Simpson and Mr. Jaw-Long Tsou made helpful comments. Marylou Zickl and Tom Zimmerman did the typing and drafting.

Financial support from the National Science Foundation by contrast NSF C-482 to collect the data presented here and by the Atomic Energy Commission grant AT(11-1) 2185 to interpret the results is gratefully acknowledged.

\section{REFERENCES}

Ben-Yaakov, S. and Kaplan, I. R., 1971. Deep sea in situ carbonate saturometry. J. Geophys. Res. 76, 722.

Berner, R. A., 1965. Activity coefficients of bicarbonate, carbonate, and calcium ions in sea water. Geochim. Cosmochim. Acta. 29, 947.

Bohr, C., 1899. Definition and Methode zur Bestimmung der Innvasions-und Evasionskoefficienten beider Auflösung von Gasen in Flüssigkeit. Ann. Phys. Chem. $68,500$.

Buch, K., 1951. Das Kohlensaüre-Gleichgewichtssystem im Meerwasser. Hansforshkn Inst. Skr. No. 151. Helsingfors.

Disteche, A. and Disteche, S., 1967. The effect of pressure on the dissociation of carbonic acids from measurements with buffered glass electrode cells: The effects of $\mathrm{NaC1}$, $\mathrm{KCl}, \mathrm{Mg}^{++}, \mathrm{Ca}^{++}, \mathrm{SO}_{4}=$, and of boric acid with special reference to sea water. J. Electrochem. Soc. 114, 330.

Garrels, R. M. and Thompson, M. E., 1962. A chemical model for sea water at $25^{\circ} \mathrm{C}$ and one atmosphere total pressure. Am. J. Sci. 360, 57.

Harned, H. S. and Davis, R., 1943. The ionization constant of carbonic acid in water and the solubility of carbon dioxide in water and aqueous salt solutions from $0^{\circ}$ to $50^{\circ}$ C. J. Am. Chem. Soc. 65, 1030.

Kester, D. R. and Pytkowicz, R. M., 1967. Determination of the apparent dissociation constants of phosphoric acid in sea water. Limnol. Oceanog. 12, 243.

Krough, A., 1904. On the tension of carbonic acid in natural waters and especially sea water. Medd. Groenland. 26, 331 .
Li, Y.-H., Takahashi, T., and Broecker, W. S., 1969. Degree of saturation of $\mathrm{CaCO}_{3}$ in the oceans. J. Geophys. Res. $74,5507$.

Li, Y.-H. and Tsui, T. F., 1971. The solubility of $\mathrm{CO}_{2}$ in water and sea water. J. Geophys. Res. 76, 4203.

Lyman, J., 1957. Buffer mechanism of sea water. Ph.D. Thesis, Univ. California, Los Angeles. 196 p.

MacIntyre, W. G., 1965. The temperature variation of the solubility product of calcium carbonate in sea water. Fisheries Res. Board Canada Manuscript Rept. Ser. No. 200. $153 \mathrm{p}$.

Simpson, H. J., 1970. Closed basin lakes as a tool in geochemistry. Ph.D. Thesis, Columbia University. 325 p.

Suess, E., 1970. Interaction of organic compounds with calcium carbonate-I. Association phenomena and geochemical implications. Geochim. Cosmochim. Acta. 34, 157.

Takahashi, T., Weiss, R. F., Culberson, C. H., Edmond, J. M., Hammond, D. E., Wong, C.S., Li, Y.-H. and Bainbridge, A. E., 1970. A carbonate chemistry profile at the 1969 GEOSECS intercalibration station in the eastern Pacific Ocean. J. Geophys. Res. 75, 7648.

Weyl, P. K., 1967. The solution behavior of carbonate materials in sea water. Studies Trop. Oceanogr. Miami. 5, 178.

\section{OTHER REFERENCES NOT CITED}

Edmond, J. M., 1970. The carbonic acid system in sea water. PhD Thesis, Univ. California, San Diego, 172 p.

Edmond, J. M. and Gieskes, J. M. T. M., 1970. On the calculation of the degree of saturation of sea water with respect to calcium carbonate under in situ conditions. Geochim. Cosmochim. Acta. 34, 1261.

Sverdrup, H. W., Johnson, M. W. and Fleming, R. H., 1942. The Oceans. Englewood Cliffs, N. J. (Prentice Hall). $1060 \mathrm{p}$.

Wattenberg, H. and Timmermann, E., 1936. Uber die Sattigung des Seewassers an $\mathrm{CaCO}_{3}$, und die anorganogene Bildung von Kalksedimenten. Ann. Hydrogr. Mar. Meteoral. 23. 


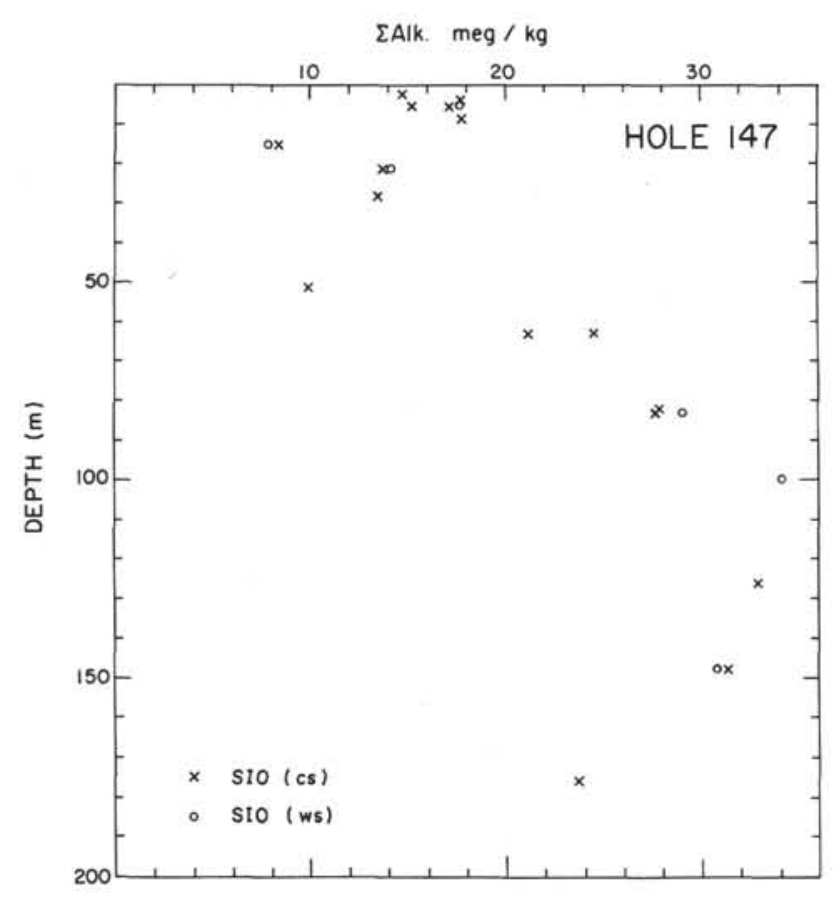

Figure 13. Site 147 alkalinity profile.

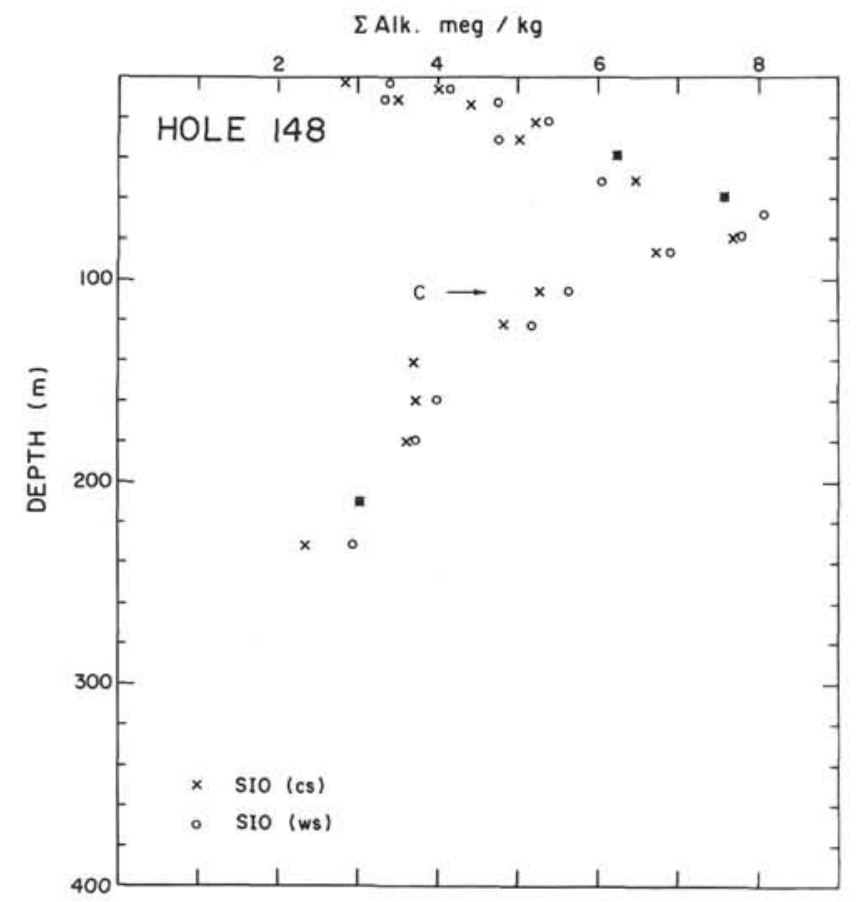

Figure 14. Site 148 alkalinity profile. $C=$ contamination with fresh water during drilling.

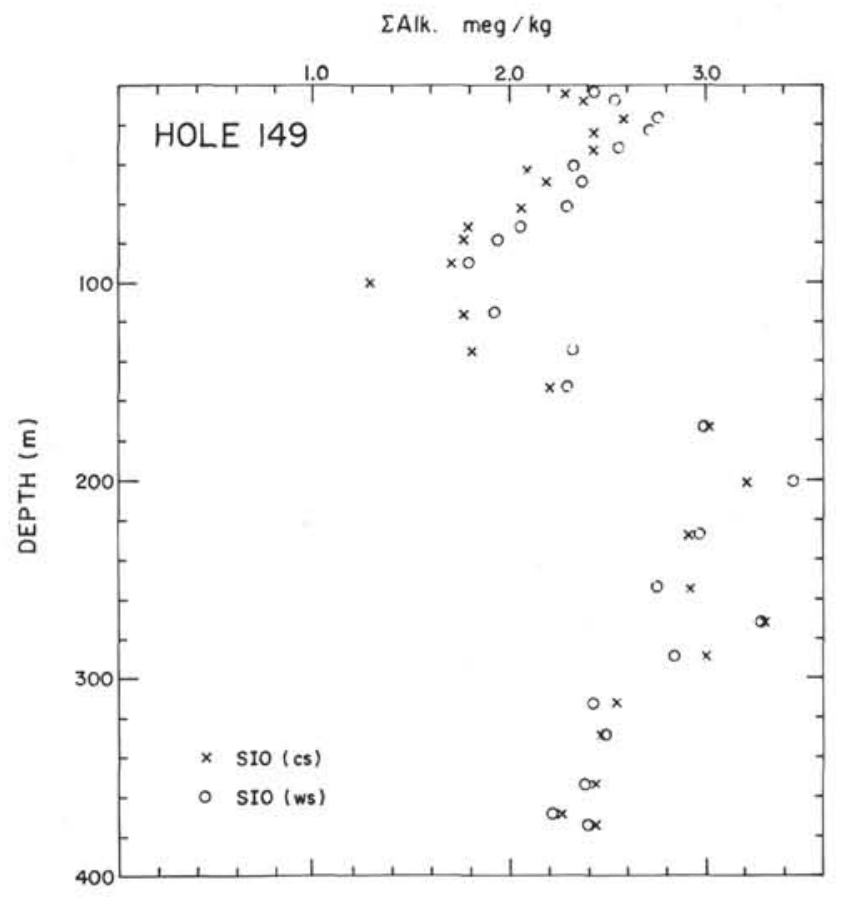

Figure 15. Site 149 alkalinity profile.

TABLE 6

The Effect of Warming on Alkalinity Changes

\begin{tabular}{cccl}
\hline & \multicolumn{2}{c}{ WS-CS } & \\
\cline { 2 - 3 } Region & $\begin{array}{c}\text { mmol/kg } \\
\mathrm{CaCO}_{3} \\
\text { Dissolved }\end{array}$ & $\begin{array}{c}\text { meq/kg } \\
\text { Acid } \\
\text { Released }\end{array}$ & \multicolumn{1}{c}{ Sediment Type } \\
\hline Site 147 & +0.7 & 1.2 & $\begin{array}{l}\text { Calcareous and dolomitic } \\
\text { clay }\end{array}$ \\
Site 148 & & & \\
$3-26 \mathrm{~m}$ & +0.2 & 0.3 & \\
$27-63 \mathrm{~m}$ & -0.2 & -0.2 & Marls and calcareous clays \\
$64-232 \mathrm{~m}$ & +0.3 & +0.3 & \\
Site 149 & +0.2 & +0.2 & $\begin{array}{l}\text { Marls, clays, and chalk } \\
4-239 \mathrm{~m}\end{array}$ \\
$240-374 \mathrm{~m}$ & -0.1 & -0.1 & $\begin{array}{l}\text { Radiolarian chalk } \\
\text { (abundant radiolaria) }\end{array}$ \\
\hline
\end{tabular}


MAJOR ELEMENT AND CARBONATE CHEMISTRY DATA, SITES 147, 148, AND 149

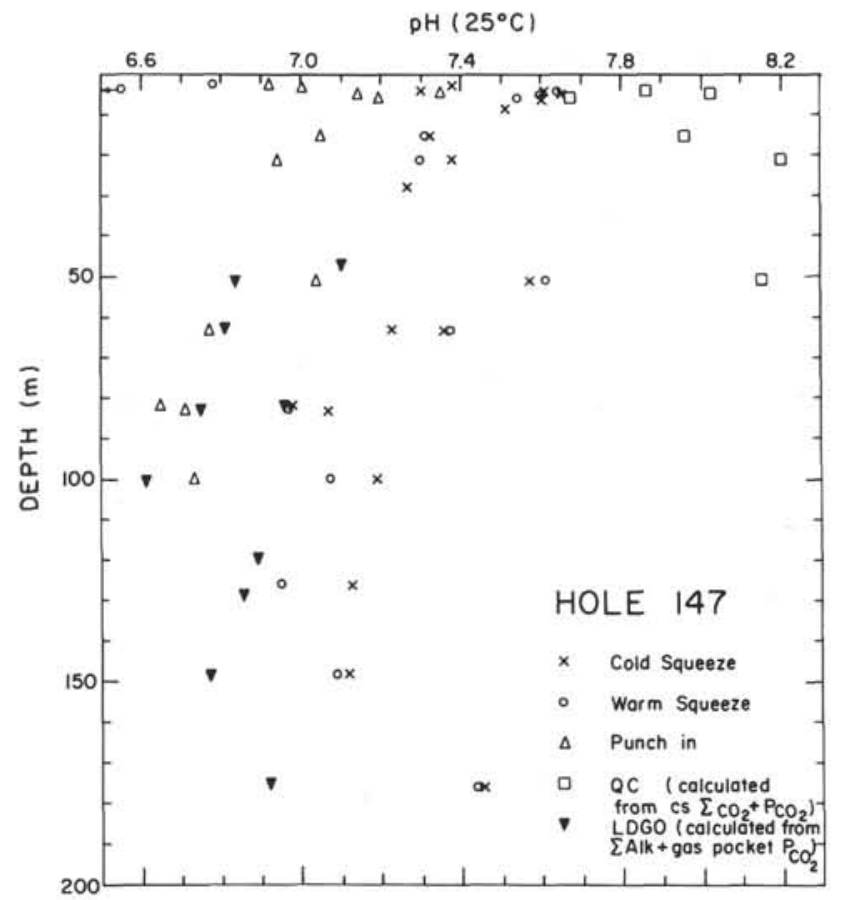

Figure 16. Site $147 \mathrm{pH}$ profile (calculated at $25^{\circ} \mathrm{C}$ ).

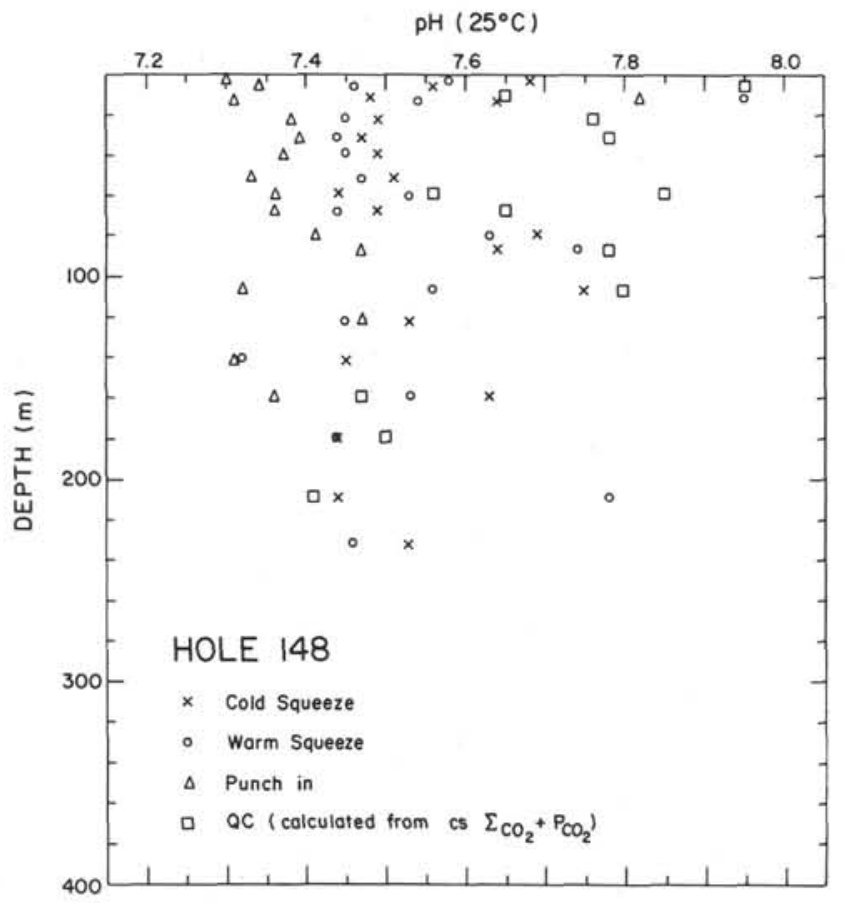

Figure 17. Site $148 \mathrm{pH}$ profile (calculated at $25^{\circ} \mathrm{C}$ ). $\mathrm{C}=$ contamination with fresh water during drilling.

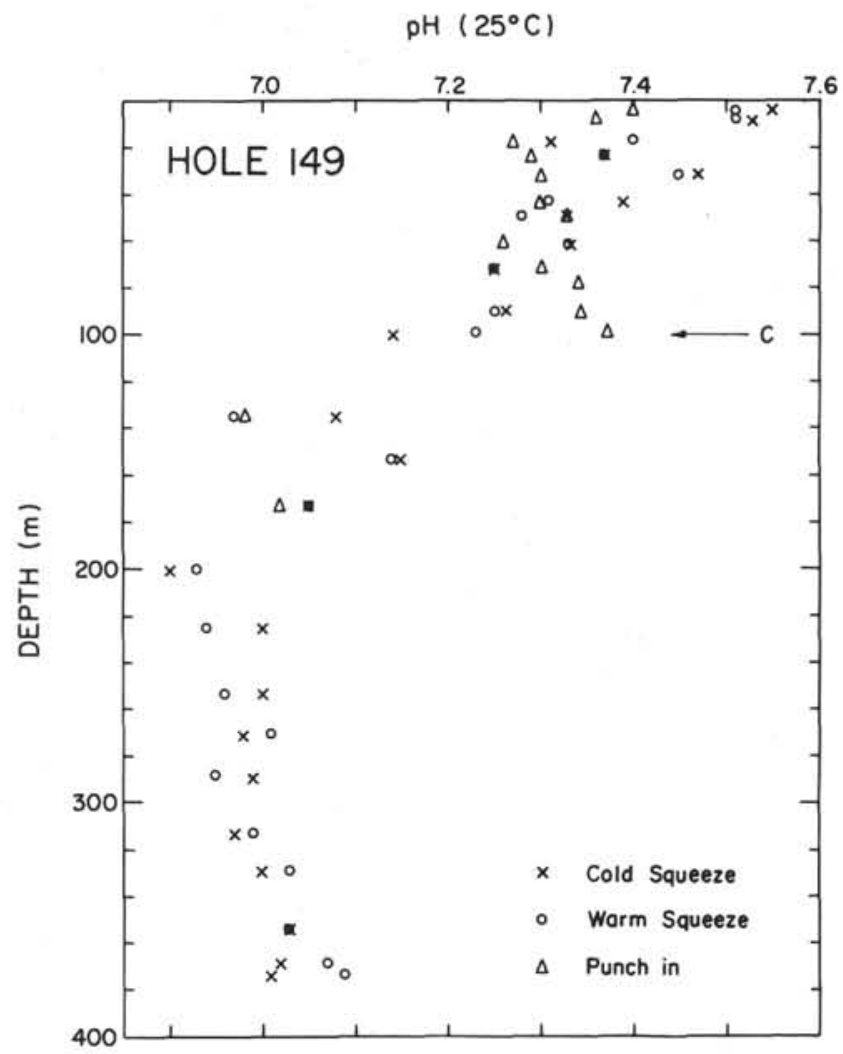

Figure 18. Site $149 \mathrm{pH}$ profile (calculated at $25^{\circ} \mathrm{C}$ ). $\mathrm{C}=$ contamination with dye during drilling.

847 
TEMPERATURE $\left({ }^{\circ} \mathrm{C}\right)$

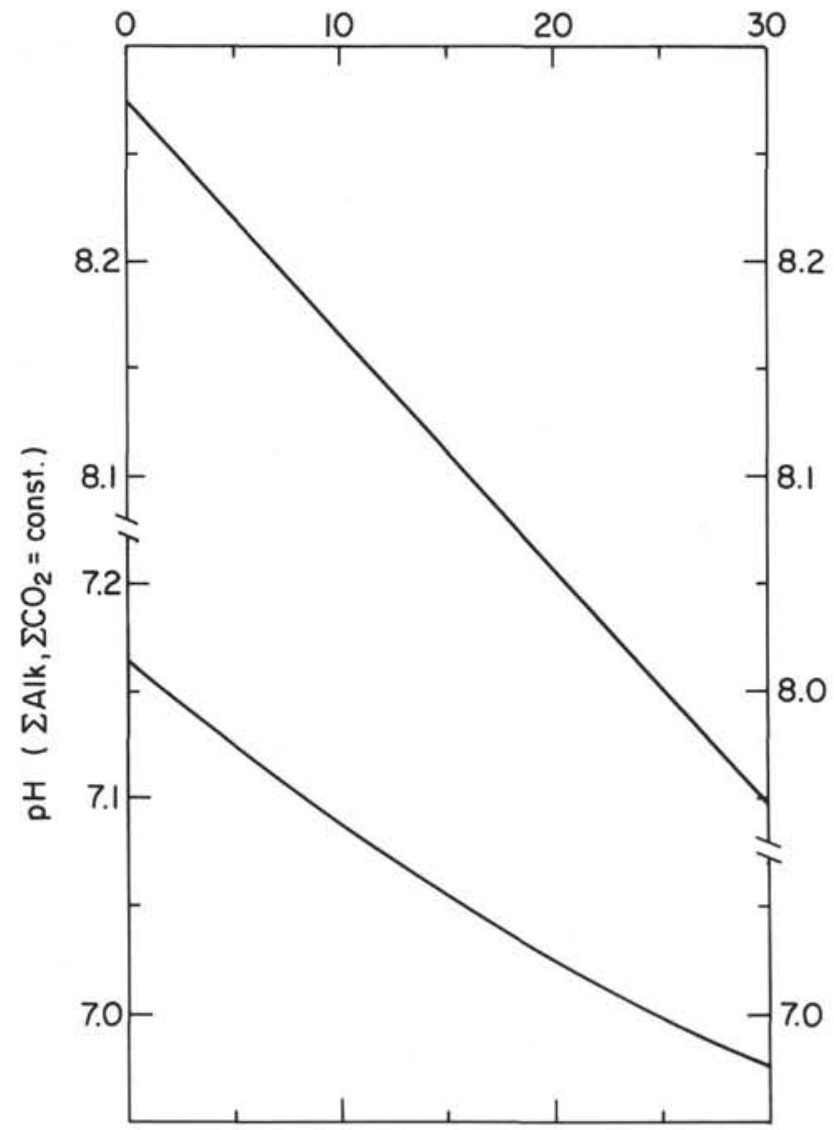

Figure 19. Effect of temperature on $\mathrm{pH}$ of pore water with constant $\Sigma \mathrm{CO}_{2}$ and $\Sigma$ alkalinity.

TABLE 7

Comparison of $p \mathrm{H}$ (Recalculated to $25^{\circ} \mathrm{C}$ ) Measurements (Median Differences in $p \mathrm{H}$ Units)

\begin{tabular}{|c|c|c|c|c|}
\hline Region & CS-WS & WS-PI & $\begin{array}{c}\text { Median } \\
\text { Temperature } \\
\text { of PI } \\
\text { Measurement }\end{array}$ & Sediment Type \\
\hline Site 147 & +0.06 & +0.30 & $25.4^{\circ} \mathrm{C}$ & $\begin{array}{l}\text { Calcareous and dolo- } \\
\text { mitic clay }\end{array}$ \\
\hline $\begin{array}{l}\text { Site } 148 \\
\text { Site } 149\end{array}$ & +0.06 & +0.14 & $19.0^{\circ}$ & Marls and clays \\
\hline $\begin{array}{l}0-66 \mathrm{~m} \\
67-262 \mathrm{~m}\end{array}$ & +0.02 & +0.10 & $20.0^{\circ} \mathrm{C}$ & $\begin{array}{l}\text { Marls and chalk, first } \\
\text { radiolaria appear at }\end{array}$ \\
\hline $\begin{array}{l}67-262 \mathrm{~m} \\
263-374 \mathrm{~m}\end{array}$ & -0.03 & -0.07 & $20.0^{\circ} \mathrm{C}$ & $\begin{array}{l}\text { Radiolarian ooze and } \\
\text { chalk }\end{array}$ \\
\hline
\end{tabular}

TABLE 8

Errors in Calculation of $\Omega$

\begin{tabular}{ll}
\hline \multicolumn{1}{c}{ Source } & \multicolumn{1}{c}{ Magnitude } \\
\hline$\left[\mathrm{Ca}^{++}\right]$ & $\pm 5 \%$ \\
$\Sigma$ alkalinity & $\pm 0.5 \%$ \\
${ }^{\mathrm{a}} \mathrm{H}^{+}$ & $\pm 0.05 \mathrm{pH}$ units $\approx \pm 12 \%$ \\
$\mathrm{MACE}$ & $\pm 10 \%$ \\
Total & $\pm 28 \%$ \\
\hline
\end{tabular}

CALCITE SATURATION, $\left[\mathrm{CO}^{++}\right]\left[\mathrm{CO}_{3}^{\mp}\right] / \mathrm{K}_{\text {SP }}$

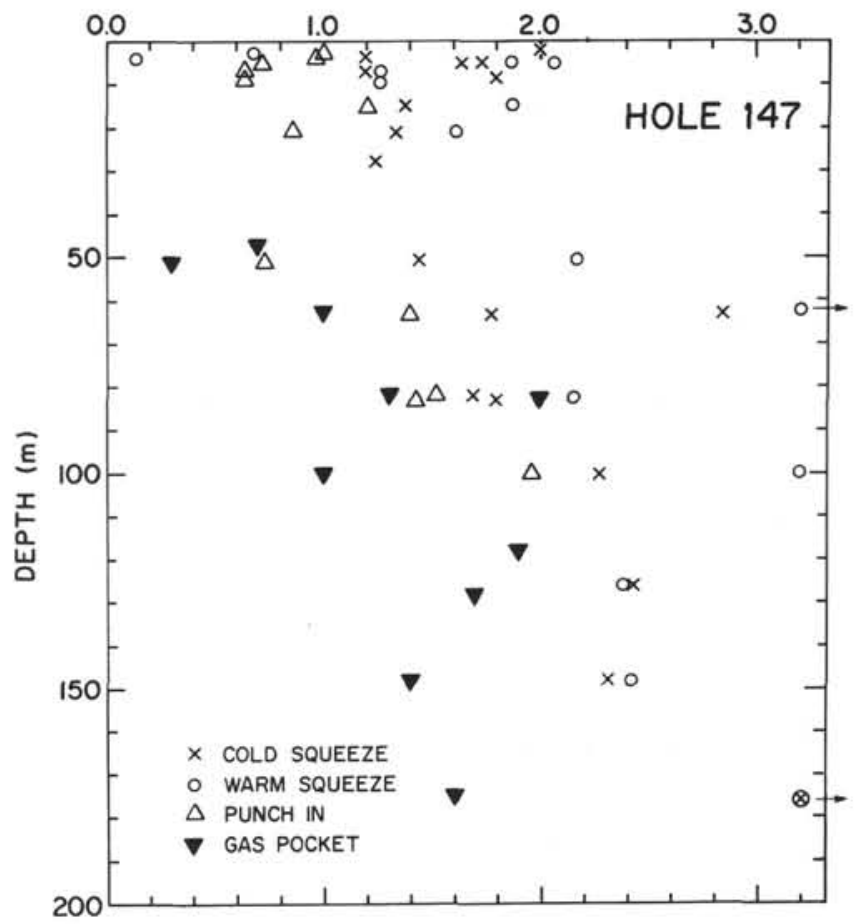

Figure 20. Site 147. Degree of saturation for calcite lat sample collection temperature and pressure). 


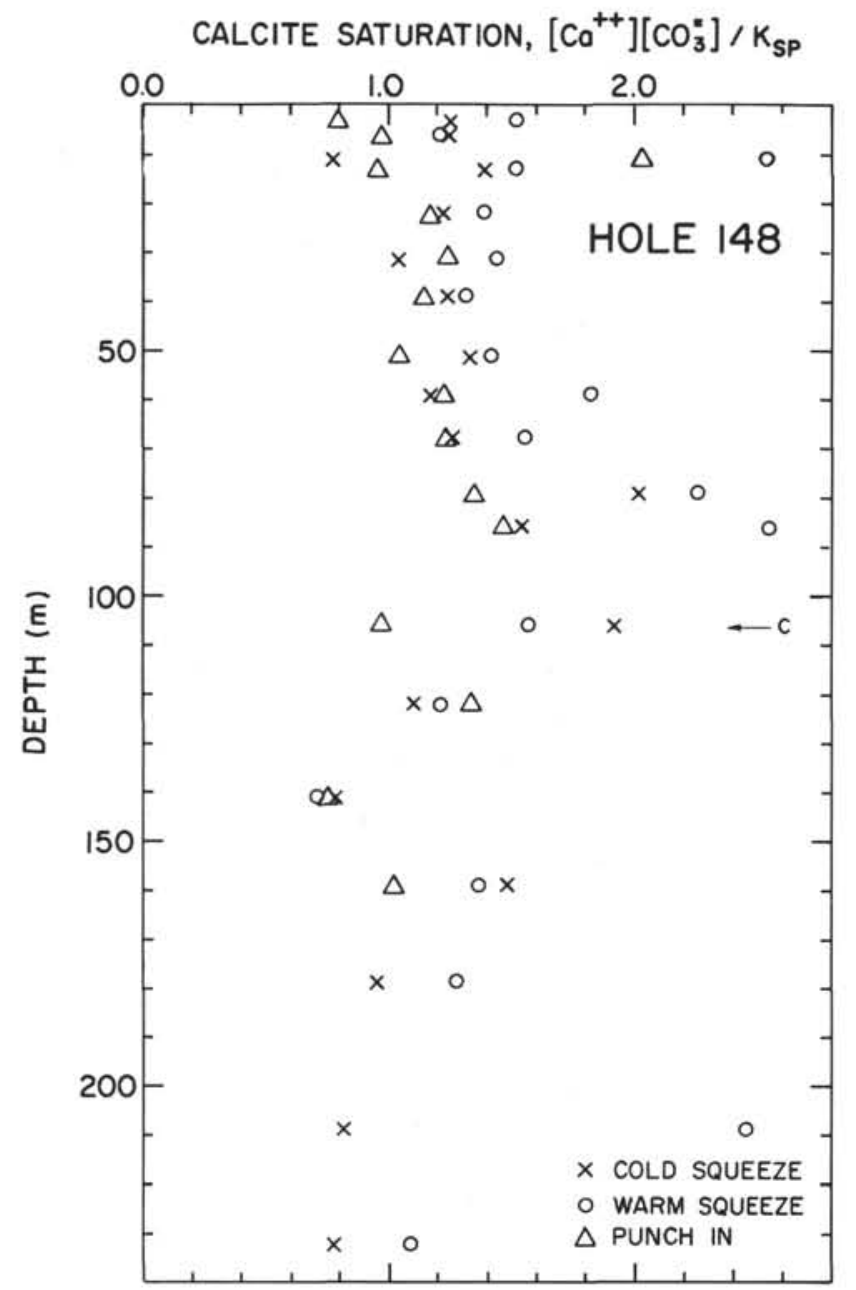

Figure 21. Site 148. Degree of saturation for calcite (at sample collection temperature and pressure).

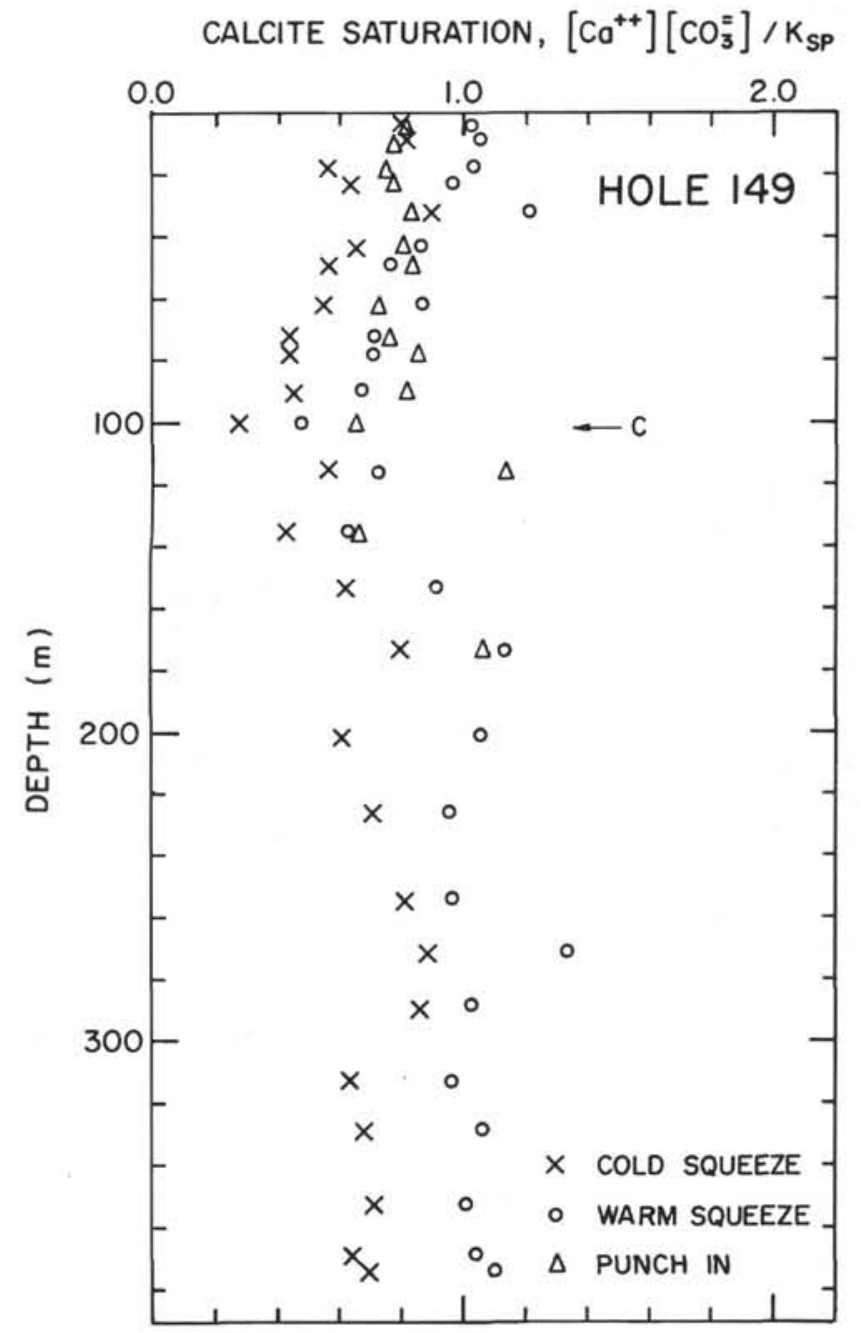

Figure 22. Site 149. Degree of saturation for calcite (at sample collection temperature and pressure). $C=$ contamination with dye during drilling.

TABLE 9

Summary of $\Omega$ Calculations

\begin{tabular}{|c|c|c|c|}
\hline & $\mathrm{CS}$ & WS & PI \\
\hline $\begin{array}{l}\text { Site } 147 \\
(<90 \mathrm{~m}) \\
(>90 \mathrm{~m})\end{array}$ & $\begin{array}{l}1.76 \pm 0.37 \\
\text { Systematic inc }\end{array}$ & $\begin{array}{l}1.97 \pm 0.33 \\
\text { ease to about } 2.6\end{array}$ & $1.00 \pm 0.20$ \\
\hline Site 148 & $1.30 \pm 0.30$ & $1.49 \pm 0.22$ & $1.12 \pm 0.21$ \\
\hline Site 149 & $0.67 \pm 0.17$ & $1.01 \pm 0.17$ & $0.80 \pm 0.06$ \\
\hline
\end{tabular}




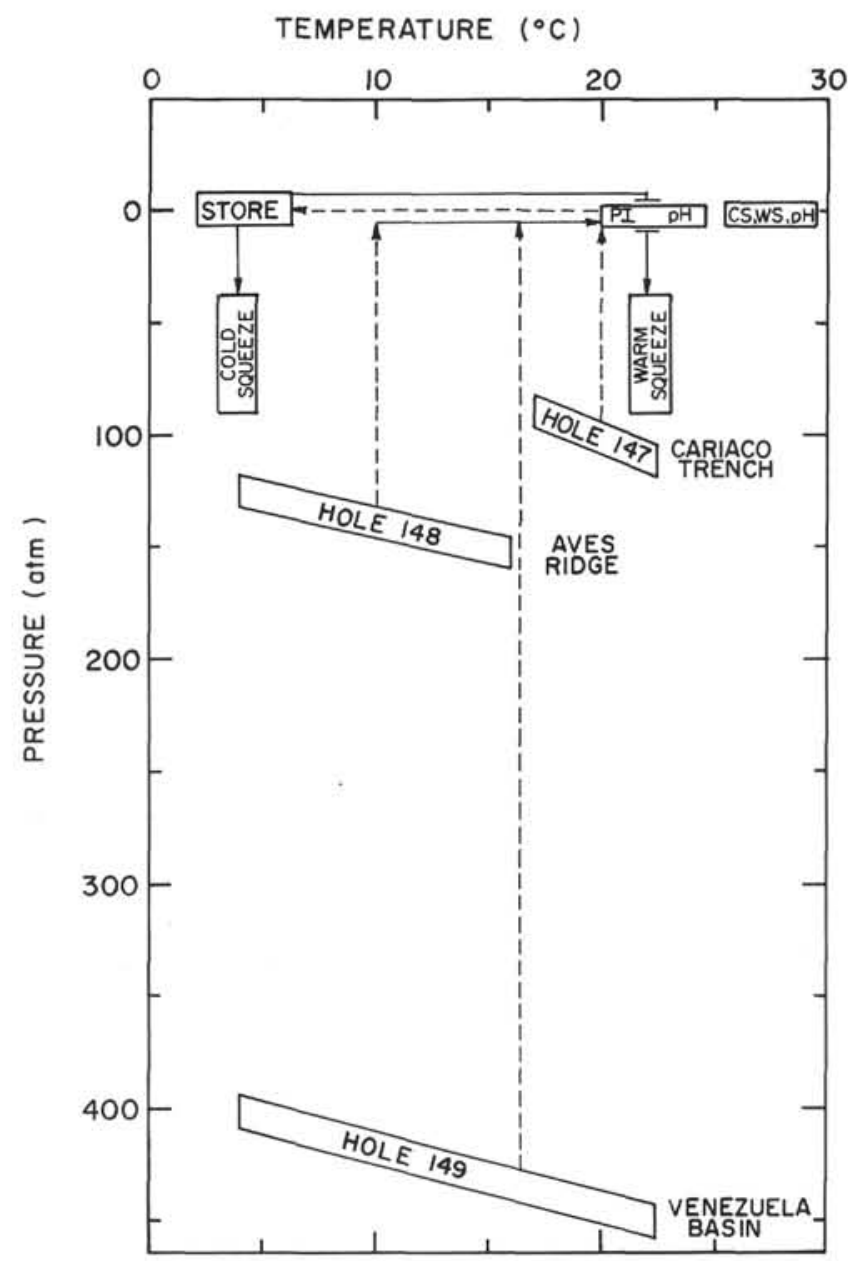

Figure 23. Pressure and temperature history of samples. Dashed lines represent environmental changes which should cause calcite precipitation and solid lines those which result in calcite solution. 